\title{
Kinase activity profiling identifies putative downstream targets of cGMP/PKG signaling in inherited retinal neurodegeneration
}

\author{
Authors \\ Akanksha Roy ${ }^{1,2^{*}}$, Arianna Tolone ${ }^{3}$, Riet Hilhorst ${ }^{2}$, John Groten ${ }^{1,2}$, Tushar Tomar ${ }^{2}$ and Francois-Paquet \\ Durand $^{3 \#}$ \\ *These authors contributed equally. \\ \# to whom correspondence should be addressed. \\ Affiliations \\ ${ }^{1}$ Division of Toxicology, Wageningen University and Research, Stippeneng 4, 6708 WE Wageningen, The Netherlands \\ ${ }^{2}$ PamGene International B.V., P.O. Box 1345, 5200 BJ 's-Hertogenbosch, The Netherlands \\ ${ }^{3}$ Cell Death Mechanism Group, Institute for Ophthalmic Research, Eberhard-Karls-Universität Tübingen, 72072, Germany
}

\begin{abstract}
Inherited retinal diseases (IRDs) are a group of neurodegenerative disorders that lead to photoreceptor cell death and eventually blindness. IRDs are characterised by a high genetic heterogeneity, making it imperative to design mutation-independent therapies. Mutations in a number of IRD disease genes have been associated with a rise of cyclic 3',5'-guanosine monophosphate (cGMP) levels in photoreceptors. Accordingly, the cGMP-dependent protein kinase (PKG) has emerged as a new potential target for the mutation-independent treatment of IRDs. However, the substrates of PKG and the downstream degenerative pathways triggered by its activity have yet to be determined. Here, we performed kinome activity profiling of different murine organotypic retinal explant cultures (diseased $r d 1$ and wild-type controls) using multiplex peptide microarrays to identify proteins whose phosphorylation was significantly altered by PKG activity. In addition, we tested the downstream effect of a known PKG inhibitor CNO3 in these organotypic retina cultures. Among the PKG substrates were potassium channels belonging to the $\mathrm{K}_{\mathrm{v}} 1$ family (KCNA3, KCNA6), Cyclic AMP-responsive element-binding protein 1 (CREB1), DNA topoisomerase 2- $\alpha$ (TOP2A), 6-phosphofructo-2-kinase/fructose-2,6-biphosphatase 3 (F263), and the glutamate ionotropic receptor kainate 2 (GRIK2). The retinal expression of these PKG targets was further confirmed by immunofluorescence and could be assigned to various neuronal cell types, including photoreceptors, horizontal cells, and ganglion cells. Taken together, this study confirmed the key role of PKG in photoreceptor cell death and identified new downstream targets of cGMP/PKG signalling that will improve the understanding of the degenerative mechanisms underlying IRDs.
\end{abstract}

\section{Key words}

cGK1, cGK2, apoptosis, retinitis pigmentosa, F263 


\section{Introduction}

Inherited retinal degeneration (IRD) relates to a genetically highly heterogeneous group of neurodegenerative diseases causing photoreceptor cell death and eventually blindness $(1,2)$. To this day, in almost all cases, these diseases are untreatable. Causative mutations have been identified in over 300 different disease genes (https://sph.uth.edu/retnet; information retrieved September 2021), calling for the development of mutation-independent therapies. Mutations in more than 20 IRD disease genes have been linked to increased levels of cyclic 3',5'-guanosine monophosphate (cGMP) in photoreceptors (3) and are thought to affect at least 30\% of IRD patients (4). A key effector of cGMPsignalling is cGMP-dependent protein kinase (PKG), the overactivation of which may trigger photoreceptor cell death $(3,5)$.

Mammals possess two different genes encoding for PKG, prkg1 and prkg2 (6). Splicing of prkg1 leads to two distinct isoforms - PKG1 $\alpha$ and PKG2 $\beta$ - which differ in their first 80 to 100 amino acids. The prkg2 gene gives rise to only one isoform called PKG2. PKGs exist as a homodimer and binding of cGMP to one of the four CGMP binding sites induces a conformational change which activates the kinase (6). Activated PKG phosphorylates numerous cellular proteins at serine/threonine amino acid positions, which in turn regulate numerous cellular pathways. In mammals, PKG1 regulates smooth muscle contraction (7), platelet activation and adhesion (8), cardiac function (9), feedback of the NOsignalling pathways (10), and various processes in the central nervous system, such as hippocampal and cerebellar learning (11). PKG2 is involved in translocation of CFTR channels in jejunum (12) and regulation of bone growth by activation of kinases such as MAPK3/ERK1 and MAPK1/ERK2 in mechanically stimulated osteoblasts (13).

Intriguingly, PKG also plays an important role in cell death, which has been ascertained, for instance, through studies where PKG activation inhibited tumour progression in colon cancers, breast cancers, ovarian cancers and melanoma $(14,15)$. Furthermore, PKG seems to play a central role in photoreceptor degeneration (16-18). In the $r d 1$ mouse retina, a well characterised model for IRD, photoreceptor cell death is triggered by abnormally high concentrations of retinal cGMP. This event is linked to dysfunction of phosphodiesterase 6 (PDE6) - involved in the regulation of intracellular cGMP levels - caused by a nonsense mutation in the rod Pde6b gene (19). Increased cGMP signalling has been found in several other models for IRDs $(4,16)$ and is likely to over-activate PKG $(20)$. In vitro and in vivo pharmacological inhibition of PKG showed strong photoreceptor protection in $r d 1$ retina as well as in the retina of $r d 2$ and $r d 10$ mouse models $(20,21)$. Together, these studies suggest a key role for PKG activity in cGMP-mediated cell death and highlight PKG as a potential common target for strategies aiming to reduce photoreceptor degeneration. 
bioRxiv preprint doi: https://doi.org/10.1101/2021.09.10.459762; this version posted September 11, 2021. The copyright holder for this preprint (which was not certified by peer review) is the author/funder, who has granted bioRxiv a license to display the preprint in perpetuity. It is made available under aCC-BY-NC-ND 4.0 International license.

Roy, Tolone et al., 2021 PKG activity profile in retinal degeneration.

The pathways downstream of PKG in degenerating photoreceptors are nonetheless still poorly understood. Increased cGMP/PKG signalling has been associated with increased activity of poly-ADPribose-polymerase (PARP), histone deacetylase (HDAC), and calpain proteases, all known to be involved in photoreceptor cell death (16). However, to date there is no evidence that directly links these events to PKG. Intracellular changes of known PKG targets such as vasodilator-stimulated phosphoprotein (VASP) and cAMP response element-binding protein (CREB) have been observed in dying photoreceptors $(18,22,23)$. While this can be a direct consequence of excessive cGMP/PKG signalling, these targets may also be phosphorylated by or have phosphorylation sites for other kinases, including CAMP-dependent protein kinase (PKA), characterised by substrate motifs similar to those of PKG (24). A better insight into the downstream effects of PKG and its phosphorylation targets is needed to understand the mechanisms of photoreceptor cell death and to, furthermore, guide the development of both new neuroprotective strategies and biomarker applications.

Using multiplex peptide microarrays, PamChips ${ }^{\circledR}$, we measured PKG1- and PKG2- mediated phosphorylation of specific peptides on lysates of murine retinal explant cultures treated or not with the PKG inhibitor CNO3 (21). We identified several new PKG substrates potentially connected to IRD and confirmed their retinal expression in murine tissue. This study thus provides the groundwork for future studies aimed at the elucidation of cGMP/PKG-dependent cell death pathways.

\section{Results}

\section{PKG inhibition reduces photoreceptor cell death in rd1 retinal explants}

To investigate potential targets of PKG and their possible role in photoreceptor cell death, we used the PKG inhibitor CNO3 on rd1 organotypic retinal explant cultures. CNO3 is a cGMP analogue, and as such is able to bind to CGMP binding sites on PKG, without inducing the conformational changes required for kinase activation (25). This culminates in reversible and competitive inhibition of PKG. In previous studies, $\mathrm{CNO} 3$ showed marked protection of photoreceptors in retinal explants derived from the $r d 1$ mouse model $(21,26)$. We therefore collected wild-type (WT) and $r d 1$ retinal explants treated or not with $50 \mu \mathrm{M} \mathrm{CNO3,} \mathrm{using} \mathrm{a} \mathrm{treatment} \mathrm{paradigm} \mathrm{based} \mathrm{on} \mathrm{the} \mathrm{aforementioned} \mathrm{studies.} \mathrm{Thus,}$ retinas were explanted at postnatal $(P)$ day 5 when photoreceptor degeneration had not yet started. The $\mathrm{CNO} 3$ treatment was given at $\mathrm{P} 7$ and $\mathrm{P} 9$ and cultures were terminated at P11. The latter timepoint corresponds to the beginning of $r d 1$ photoreceptor cell death (27), and is thus well suited to assess the protective effects of a given compound and to study events downstream of abnormal cGMP/PKG signalling. We confirmed the protective effects of $\mathrm{CNO3}$, by characterising the degree of cell death using the TUNEL assay (Figure 1). CNO3-treated retinas showed marked photoreceptor protection as previously reported (21). 
bioRxiv preprint doi: https://doi.org/10.1101/2021.09.10.459762; this version posted September $11,2021$. The copyright holder for this preprint (which was not certified by peer review) is the author/funder, who has granted bioRxiv a license to display the preprint in perpetuity. It is made available under aCC-BY-NC-ND 4.0 International license.
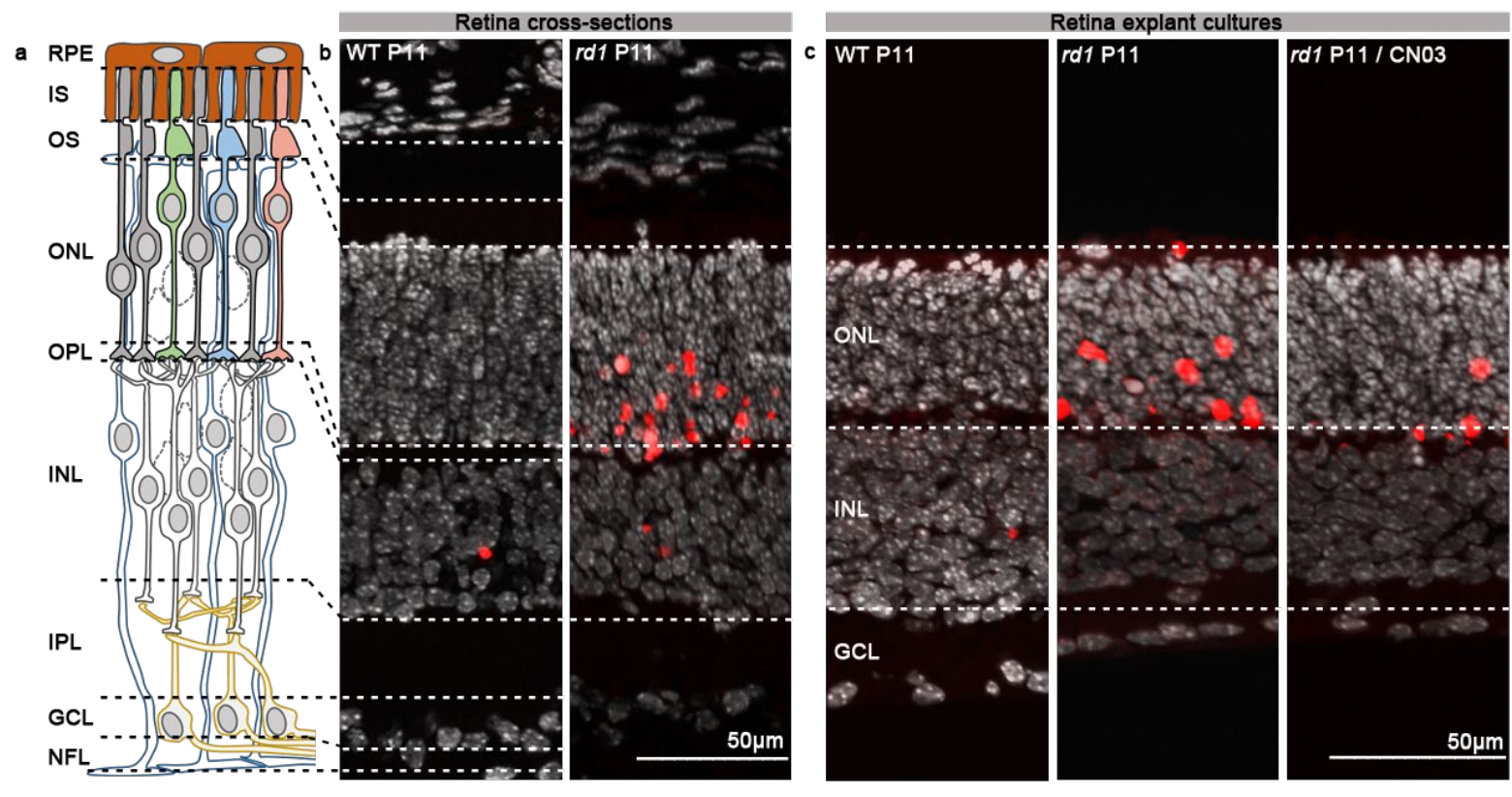

Figure 1: CN03-mediated photoreceptor protection in rd1 P11 retinal explants. a) Diagram showing retinal layers: RPE=retina pigment epithelium, IS=inner segment, OS=outer segment, ONL=outer nuclear layer, $\mathrm{OPL}=$ outer plexiform layer, INL=inner nuclear layer, IPL=inner plexiform layer, $\mathrm{GCL}=$ ganglion cell layer, NFL=nerve fibre layer. $\mathbf{b}$ ) Retina cross-sections derived from WT and $r d 1$ P11 mice. c) Sections derived from WT and $r d 1$ P11 retinal explant cultures untreated or treated from P7 to P11 with $50 \mu \mathrm{M}$ CN03. In both b and c: TUNEL assay (red) indicated dying cells, DAPI (grey) was used as nuclear counterstain. $P=$ postnatal day.

\section{Serine/Threonine Kinase (STK) activity in $r d 1$ retinal explants}

To evaluate possible differences in kinase profiles of the murine retinal explant samples $(r d 1, n=8$; WT, n=5), we used PamChip ${ }^{\circledR}$ peptide microarray-based Serine/Threonine Kinase (STK) activity assays (24). The overall STK activity between the samples is represented as heatmap (Fig. S1 a). A violin plot was used to visualize the phosphorylation signal intensity of the peptides and its distribution within the same sample groups (Fig. 2 a). Increased phosphorylation was observed for $43 \%$ of the total 142 peptides in $r d 1$ retinal explants, indicating higher kinase activity in $r d 1$ NT when compared to WT (Fig.

2 b). Among the elevated phosphorylated peptides, SRC8_CHICK_423_435, RBL2_959_971, CDN1B_151_163 and RADI_559_569 showed significantly higher phosphorylation $(p<0.05)$ in $r d 1$ explants than in wild type controls. Using the upstream kinase analysis tool of the BioNavigator ${ }^{\circledast}$ software, the peptides with increased phosphorylation were linked to kinases that are most likely to be responsible for phosphorylation of these peptides (See Data Analysis, Materials and Methods Section). The kinase statistics and kinase score were calculated as a metrics for identifying highly active kinases. The kinases that were predicted to be highly active in $r d 1$ explants include CaMK4, PKG1, PKG2, PKA $\alpha$, and Pim1 (Table 1). In order to present relative kinome activity profiles of retinal explants ( $r d 1$ vs WT), kinase score and kinase statistics were used to visualize branches and nodes on the phylogenetic tree of protein kinase family (Fig. 2 c). 
bioRxiv preprint doi: https://doi.org/10.1101/2021.09.10.459762; this version posted September 11, 2021. The copyright holder for this preprint (which was not certified by peer review) is the author/funder, who has granted bioRxiv a license to display the preprint in perpetuity. It is made available under aCC-BY-NC-ND 4.0 International license.

a

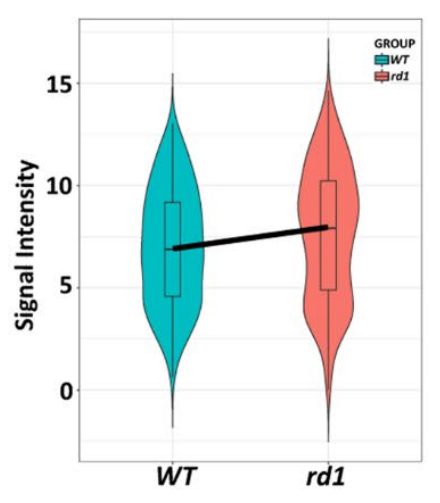

b

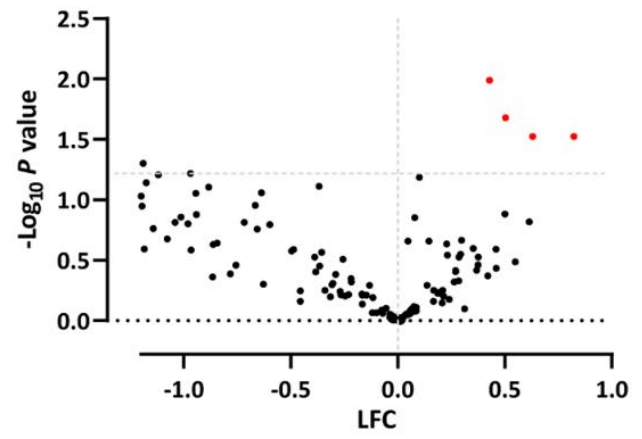

C

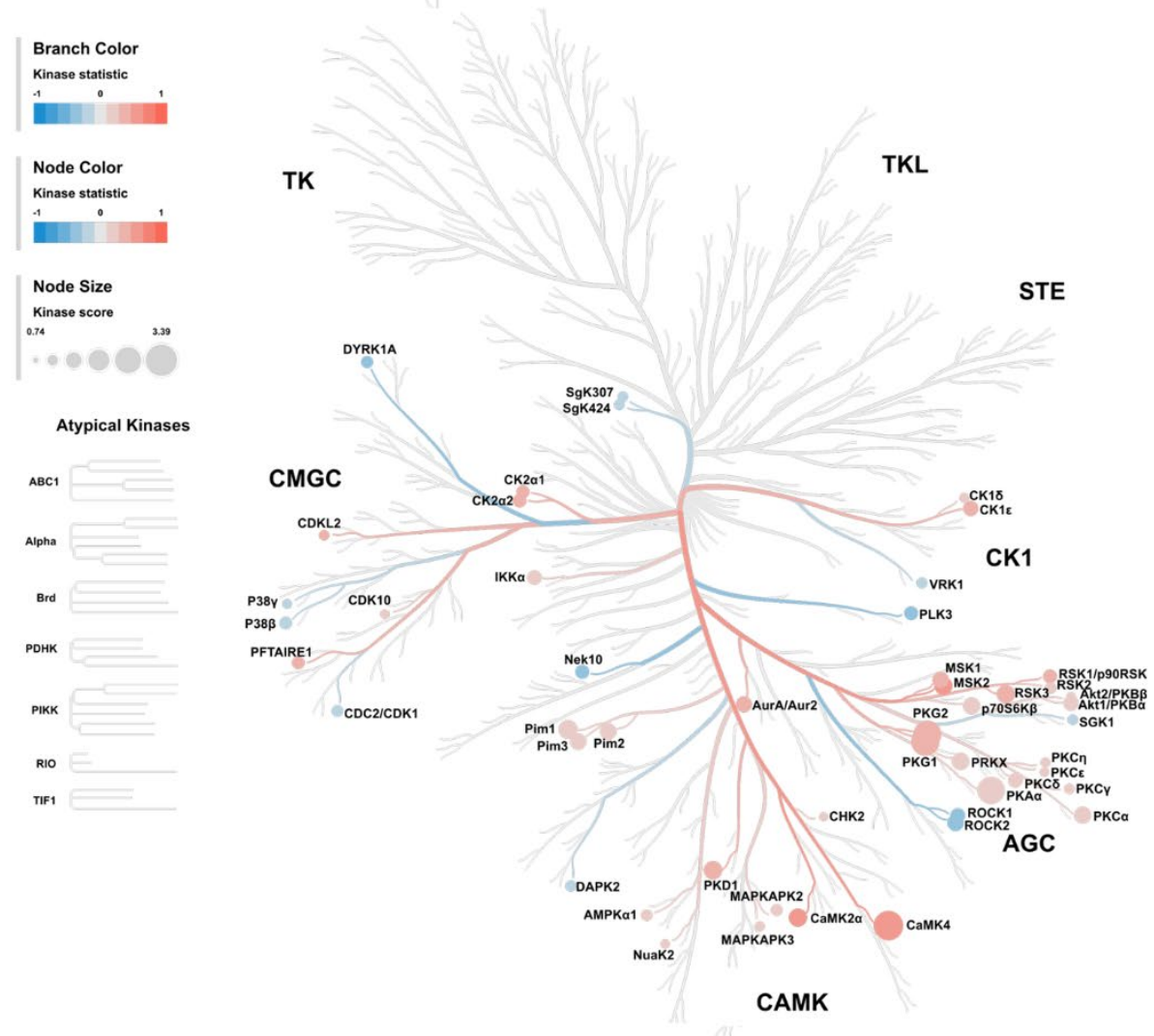

Figure 2. Serine/Threonine Kinase (STK) activity in untreated retinal explants. Organotypic retinal explants derived from wild-type (WT) and $r d 1$ mice (WT, $\mathrm{n}=5 ; r d 1, \mathrm{n}=8$ ) were treated with culture medium for four days. The kinase activity of their lysates was measured on PamChip ${ }^{\circledR}$ Serine/Threonine kinase (STK) arrays. a) Violin plot showing the global phosphorylation of the peptides on PamChip ${ }^{\circledR}$ STK array as $\log _{2}$ signal intensity and their intensity value distribution, when comparing WT to rd1 explants. The thick line connects the average phosphorylation values of each group. b) Volcano Plot representing Log Fold Change (LFC) and $-\log _{10} p$-value for peptide phosphorylation. Red dots indicate significantly changed phosphopeptides ( $p$-value $<0.05$ ), black dots represent peptides with no significant alteration in phosphorylation. c) The high-ranking kinases were visualized in a kinome phylogenetic tree, where branch and node color are encoded according to the kinase statistic value with value $>0$ (in red) representing higher kinase activity in $r d 1$ retinal explants. The kinase score is encoded in node size where kinases were ranked based on their significance and specificity in terms of set of peptides used for the corresponding kinase. 
bioRxiv preprint doi: https://doi.org/10.1101/2021.09.10.459762; this version posted September $11,2021$. The copyright holder for this preprint (which was not certified by peer review) is the author/funder, who has granted bioRxiv a license to display the preprint in perpetuity. It is made available under aCC-BY-NC-ND 4.0 International license.

Roy, Tolone et al., 2021

PKG activity profile in retinal degeneration.

Table 1. Upstream kinase analysis results for $r d 1$ vs. WT (a) and $r d 1$ CN03 vs. rd1 (b). The kinase statistic shows the overall change of the peptide set that represents a given kinase. Positive values indicate higher kinase activity in $r d 1$, while negative value indicate lower activity in $r d 1 \mathrm{CN} 03$. The kinase score includes the sum of significance and specificity score (Score greater than 1.5 shown in the table). This score indicates the significance of a change represented by the kinase statistic. The higher the score, the higher the significance of the change. The specificity score indicates the specificity of the kinase statistic in terms of the set of peptides used for the corresponding kinase. The higher the score, the less likely it is that observed kinase statistic could have been obtained using a random set of peptides from the data set.

$r d 1$ vs WT retinal explants

CN03-treated $r d 1$ vs control $r d 1$ retinal explants

\begin{tabular}{|c|c|c|c|c|c|c|}
\hline Rank & $\begin{array}{l}\text { Kinase } \\
\text { Name }\end{array}$ & Kinase Score & $\begin{array}{l}\text { Kinase } \\
\text { Statistic }\end{array}$ & $\begin{array}{l}\text { Kinase } \\
\text { Name }\end{array}$ & $\begin{array}{c}\text { Kinase } \\
\text { Score }\end{array}$ & $\begin{array}{l}\text { Kinase } \\
\text { Statistic }\end{array}$ \\
\hline 1. & CaMK4 & 3.39 & 0.46 & PKA $\alpha$ & 3.60 & -0.40 \\
\hline 2. & PKG1 & 3.23 & 0.32 & Pim1 & 3.50 & -0.40 \\
\hline 3. & PKG2 & 3.16 & 0.30 & PKG2 & 3.70 & -0.40 \\
\hline 4. & PKA $\alpha$ & 3.09 & 0.26 & PKG1 & 3.20 & -0.40 \\
\hline 5. & Pim1 & 2.02 & 0.19 & СаMK4 & 3.30 & -0.50 \\
\hline 6. & p70S6K $\beta$ & 1.78 & 0.24 & $\mathrm{PKC} \alpha$ & 3.10 & -0.40 \\
\hline 7. & CaMK2 $2 \alpha$ & 1.92 & 0.46 & Pim3 & 3.00 & -0.40 \\
\hline 8. & RSK1/p90RSK & 1.92 & 0.42 & PRKX & 3.00 & -0.40 \\
\hline 9. & MSK2 & 1.89 & 0.52 & p70S6K $\beta$ & 2.90 & -0.40 \\
\hline 10. & PKD1 & 1.95 & 0.43 & PKC $\delta$ & 2.70 & -0.40 \\
\hline 11. & PKC $\alpha$ & 1.77 & 0.23 & $\mathrm{CK} 2 \alpha 2$ & 3.70 & -0.60 \\
\hline 12. & Pim2 & 1.70 & 0.21 & RSK3 & 2.80 & -0.50 \\
\hline 13. & PRKX & 1.82 & 0.23 & RSK2 & 2.90 & -0.50 \\
\hline 14. & ROCK2 & 1.69 & -0.37 & PKC $\theta$ & 2.30 & -0.40 \\
\hline 15. & MSK1 & 1.71 & 0.36 & MSK2 & 2.40 & -0.60 \\
\hline 16. & Pim3 & 1.68 & 0.18 & $\mathrm{PKC} \varepsilon$ & 2.10 & -0.40 \\
\hline 17. & & & & MAPKAPK3 & 2.20 & -0.40 \\
\hline 18. & & & & PKC $\psi$ & 2.10 & -0.40 \\
\hline 19. & & & & MSK1 & 2.20 & -0.50 \\
\hline 20. & & & & PKD1 & 2.20 & -0.50 \\
\hline 21. & & & & $\mathrm{CHK} 2$ & 2.10 & -0.40 \\
\hline 22. & & & & Pim2 & 1.90 & -0.30 \\
\hline 23. & & & & MAPKAPK2 & 2.10 & -0.40 \\
\hline 24. & & & & SGK2 & 1.90 & -0.40 \\
\hline 25. & & & & AMPKa1 & 1.80 & -0.40 \\
\hline 26. & & & & PKN1 & 2.10 & -0.40 \\
\hline 27. & & & & $\mathrm{PKC \eta}$ & 1.80 & -0.40 \\
\hline 28. & & & & CK2 $2 \alpha$ & 2.30 & -0.40 \\
\hline 29. & & & & RSK1 & 1.80 & -0.40 \\
\hline 30. & & & & AurA/Aur2 & 1.70 & -0.50 \\
\hline 31. & & & & PRKY & 1.80 & -0.40 \\
\hline 32. & & & & Akt1 & 1.70 & -0.30 \\
\hline 33. & & & & DCAMKL1 & 1.70 & -0.50 \\
\hline 34. & & & & PKC $\beta$ & 1.70 & -0.40 \\
\hline 35. & & & & Akt2 & 1.70 & -0.30 \\
\hline 36. & & & & COT & 2.60 & -0.40 \\
\hline
\end{tabular}




\begin{tabular}{l|l|l|l|l|l|l|}
\hline 37. & & & PKCl & 1.60 & -0.40 \\
\hline 38. & & & RSKL1 & 1.60 & -0.40 \\
\hline
\end{tabular}

\section{STK activity in rd1 retinal explants treated with PKG Inhibitor CNO3}

As we found a higher phosphorylation of peptides in rd1 explants, when compared to WT explants, and with a clear role for PKGs observed, we sought to investigate the effect of the PKG inhibitor CNO3 on the STK activity. The PKG inhibitor CNO3 significantly decreased photoreceptor cell death (cf. Fig. 1). The overall STK activity profiles for treated and untreated $r d 1$ retinal explants are shown in a heatmap (Fig. S1 b). The distribution of phosphorylated peptides for both the samples is represented by a Violin plot (Fig. 3 a). Phosphorylation decreased for approximately $80 \%$ of the 142 peptides present on the STK PamChip ${ }^{\circledR}$. Fourteen peptides were identified whose phosphorylation decreased significantly $(p<0.05)$ in $r d 1 \mathrm{CNO} 3$ as compared to untreated $r d 1$ (Fig. 3 b). Table 2 shows peptides that displayed lower phosphorylation (22 peptides, $p<0.1$ ) in CNO3 treated $r d 1$ retina than untreated controls with their UniProt IDs, names of the proteins they are derived from, $p$-value, substrate preference of PKG1 and PKG2, and localization within the retina.

The designation of the peptides as PKG1- or PKG2-specific substrates is based on our recent studies where we ranked the peptides on the STK PamChip ${ }^{\circledR}$ according to their preference for PKG1 and or PKG2 (24). This preference was based on the substrate phosphorylation in response to PKG activity modulators (ATP, CGMP, CAMP, PKG activator, PKG inhibitors), in the presence of recombinant PKG1 or PKGII. In the present study, 11 of the peptides in Table 2, are substrates for both PKG1 and PKG2 and one was for PKG1 only. Among those peptides, KCNA6_504_516, NCF1_296_308, GRIK2_708_720, VTNC_390_402, ADRB2_338_350, BRCA1_1451_1463, RYR1_4317_4329, KCNA3_461_473 and VASP_150_162 have been verified to be present in the retina by literature search and/or ex vivo analysis. 
bioRxiv preprint doi: https://doi.org/10.1101/2021.09.10.459762; this version posted September 11, 2021. The copyright holder for this preprint (which was not certified by peer review) is the author/funder, who has granted bioRxiv a license to display the preprint in perpetuity. It is made available under aCC-BY-NC-ND 4.0 International license.

a

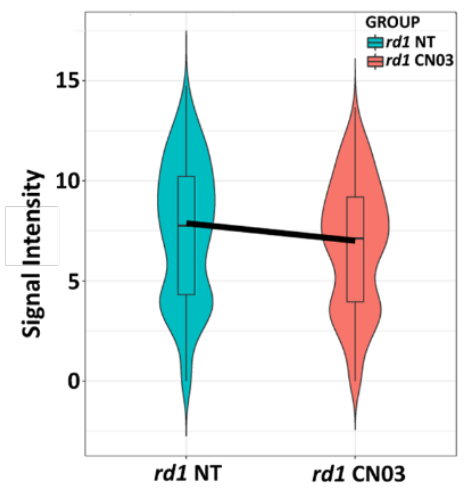

C

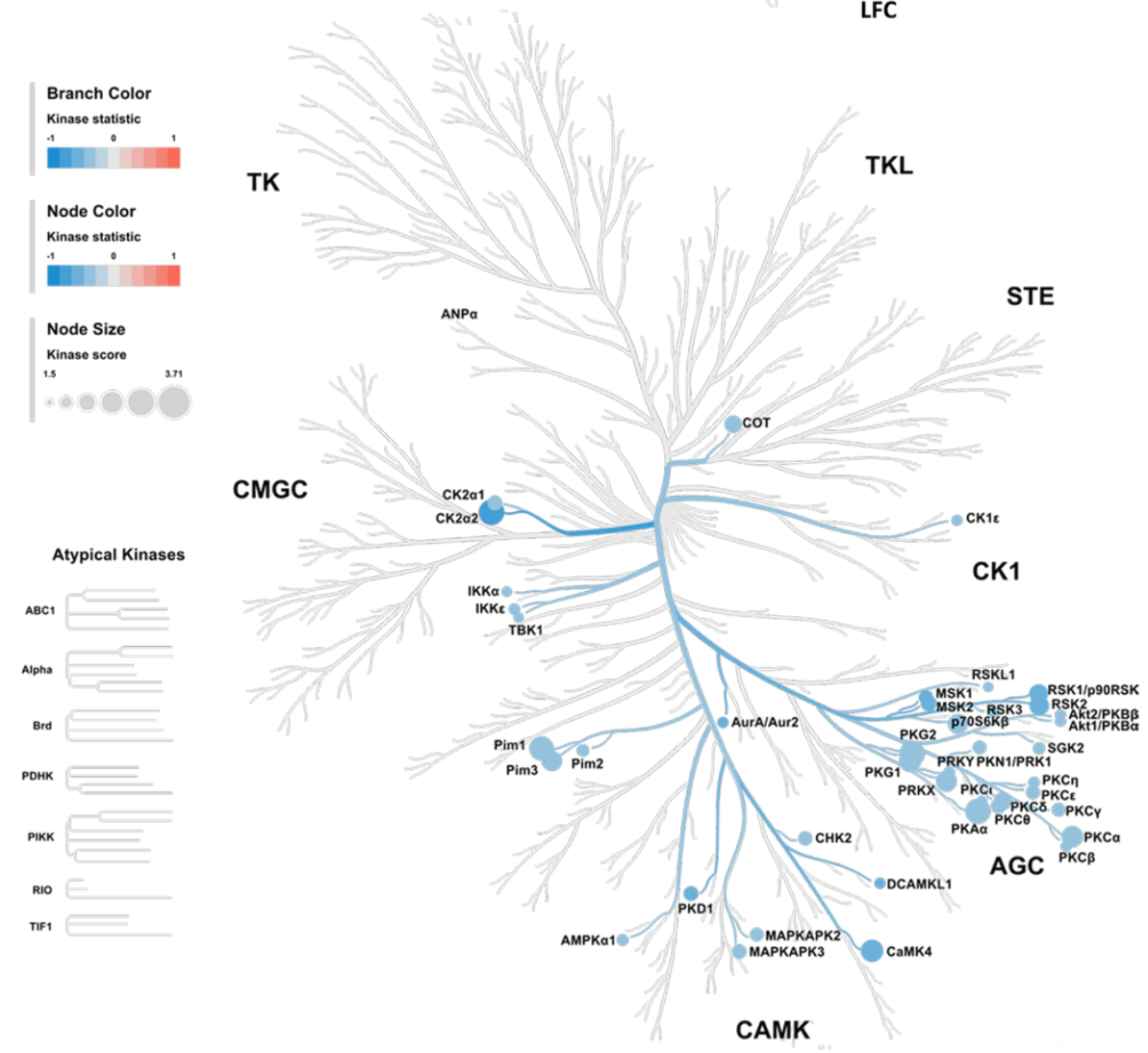

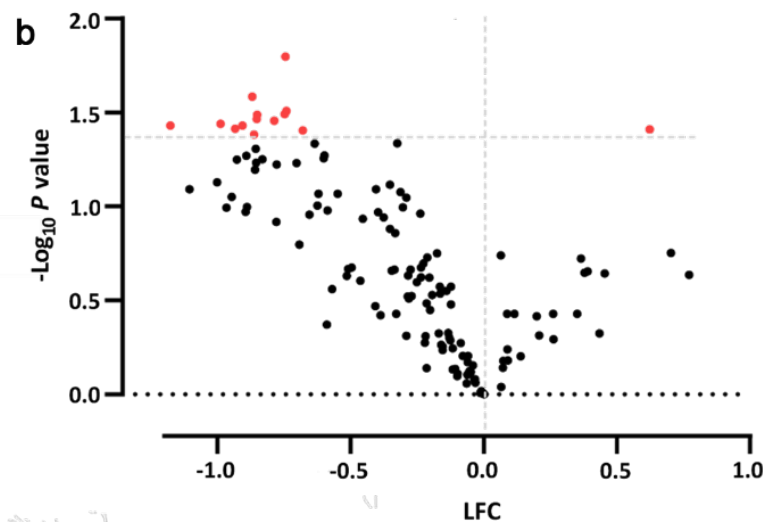

Figure 3. Serine/Threonine Kinase (STK) activity in response to PKG inhibition in retinal explants. Retinal explant cultures were either non-treated (NT) or treated with $50 \mu \mathrm{M}$ CN03 for 4 days ( $r d 1 \mathrm{NT}, \mathrm{n}=8$; rd1 CN003, $\mathrm{n}=10$ ). The kinase activity of retinal explant lysates was measured on PamChip ${ }^{\circledR}$ Serine/Threonine kinase (STK) arrays. a) Violin plot showing the global phosphorylation of peptides on the PamChip ${ }^{\circledR}$ STK array as $\log _{2}$ signal intensity and their intensity value distribution, when comparing $r d 1 \mathrm{NT}$ to $r d 1$ treated CNO3 explants. The thick line is connecting the average phosphorylation values of each group. b) Volcano Plot representing Log Fold Change (LFC) and - $\log _{10} p$ value) for peptide phosphorylation. Red dots indicate significantly changed phosphopeptides with $p$ value $<0.05$ and black dots represent phosphopeptides with no significant alteration in phosphorylation. c) The high-ranking kinases are visualized in a kinome phylogenetic Tree, where branch and node color are encoded according to the kinase statistic value with value $<0$ (in blue) representing lower kinase activity in $r d 1$ retinal explants treated with CNO3. The kinase score is encoded in node size where kinases were ranked based on their significance and specificity in terms of set of peptides used for the corresponding kinase.

We then linked the phosphorylated peptides to the putative upstream kinases and found that kinase activity of particularly PKA $\alpha$, Pim1, PKG1, PKG2, CaMK4 was suggested to be reduced by CNO3 
bioRxiv preprint doi: https://doi.org/10.1101/2021.09.10.459762; this version posted September 11, 2021. The copyright holder for this preprint (which was not certified by peer review) is the author/funder, who has granted bioRxiv a license to display the preprint in perpetuity. It is made available under aCC-BY-NC-ND 4.0 International license.

Roy, Tolone et al., 2021

PKG activity profile in retinal degeneration.

treatment (Table 1, Fig. 3 c)). Notably, these were the same kinases that were predicted to be more active in the diseased $r d 1$ explants in comparison to WT explants, indicating specific targeting by $\mathrm{CNO}$

(Fig. 2 c).

Table 2. List of potential PKG targets. Peptide substrates for PKG1and PKG2 that were differentially phosphorylated in $r d 1$ untreated vs. $r d 1$ CNO3 treated retinal explant cultures. The table shows the peptide name, UniProt ID, Protein name, $p$ value, PKG1 and PKG2 substrate specificity score, and localization in the retina with reference. The scores for PKGI, PKGII, and PKA range from 1 to 10. For substrates previously detected in the mouse retina, the reference is added. The expression of substrates printed in bold was further studied using immunodetection (cf. Fig. 4). Colour scheme according to the PKG specificity score: 10-8: Good, 7-4: Intermediate and 3-0: Poor substrate (24). For substrates known to be present in the mouse retina, the reference is added. The expression of substrates printed in bold was further studied using immunodetection (cf. Fig. 4).

\begin{tabular}{|c|c|c|c|c|c|c|c|c|}
\hline S. No. & ID & $\begin{array}{l}\text { UniProt } \\
\text { ID }\end{array}$ & Protein name & $p$ value & $\begin{array}{l}\text { PKG1 } \\
\text { score }\end{array}$ & $\begin{array}{l}\text { PKG2 } \\
\text { score }\end{array}$ & Localisation & Ref. \\
\hline 1. & IKBA_26_38 & P25963 & NF-kappa-B inhibitor alpha & 0.016 & 0 & 0 & ONL, INL, GCL & (28) \\
\hline 2. & GBRB2_427_439 & P47870 & $\begin{array}{l}\text { Gamma-aminobutyric acid } \\
\text { receptor subunit beta-2 } \\
\text { precursor }\end{array}$ & 0.026 & 10 & 6 & & \\
\hline 3. & PTN12_32_44 & Q05209 & $\begin{array}{c}\text { Tyrosine-protein phosphatase } \\
\text { non-receptor type } 12\end{array}$ & 0.031 & 10 & 5 & & \\
\hline 4. & KCNA6_504_516 & P17658 & $\begin{array}{c}\text { Potassium voltage-gated } \\
\text { channel subfamily A member } 6\end{array}$ & 0.032 & 9 & 3 & GCL & (29) \\
\hline 5. & NCF1_296_308 & P14598 & Neutrophil cytosol factor 1 & 0.032 & 9 & 7 & GCL & (30) \\
\hline 6. & CREB1_126_138 & P16220 & $\begin{array}{l}\text { cAMP response element-binding } \\
\text { protein }\end{array}$ & 0.034 & 10 & 6 & ONL, INL, GCL & \\
\hline 7. & GRIK2_708_720 & Q13002 & $\begin{array}{c}\text { Glutamate receptor, ionotropic } \\
\text { kainate } 2 \text { precursor }\end{array}$ & 0.035 & 10 & 4 & INL, IPL & (31) \\
\hline 8. & NCF1_321_333 & P14598 & Neutrophil cytosol factor 1 & 0.036 & 0 & 0 & & \\
\hline 9. & EPB42_241_253 & P16452 & $\begin{array}{l}\text { Erythrocyte membrane protein } \\
\text { band } 4.2\end{array}$ & 0.037 & 9 & 7 & & \\
\hline 10. & VTNC_390_402 & P04004 & Vitronectin precursor & 0.037 & 10 & 4 & RPE, ONL, GCL & (32) \\
\hline 11. & ADRB2_338_350 & P07550 & Beta-2 adrenergic receptor & 0.039 & 8 & 4 & Müller cells & (33) \\
\hline 12. & $\begin{array}{c}\text { BRCA1_1451_146 } \\
3\end{array}$ & P38398 & $\begin{array}{l}\text { Breast cancer type } 1 \\
\text { susceptibility protein }\end{array}$ & 0.039 & 0 & 0 & & (34) \\
\hline 13. & TOP2A_1463_147 & P11388 & DNA topoisomerase 2-alpha & 0.039 & 6 & 5 & GCL & \\
\hline 14. & MPIP3_208_220 & P30307 & M-phase inducer phosphatase 3 & 0.041 & 0 & 0 & & \\
\hline 15. & CDC2_154_169 & P06493 & $\begin{array}{l}\text { Cell division control protein } 2 \\
\text { homolog }\end{array}$ & 0.046 & 0 & 0 & & \\
\hline 16. & KAP3_107_119 & P31323 & $\begin{array}{l}\text { cAMP-dependent protein kinase } \\
\text { type II-beta regulatory subunit }\end{array}$ & 0.046 & 8 & 4 & & \\
\hline 17. & MYPC3_268_280 & Q14896 & $\begin{array}{c}\text { Myosin-binding protein C, } \\
\text { cardiac-type }\end{array}$ & 0.049 & 10 & 4 & & \\
\hline 18. & RYR1_4317_4329 & P21817 & Ryanodine receptor 1 & 0.053 & 9 & 5 & $\mathrm{ONL}, \mathrm{INL}, \mathrm{GCL}$ & (35) \\
\hline 19. & TY3H_65_77 & P07101 & Tyrosine 3-monooxygenase & 0.054 & 9 & 3 & & \\
\hline 20. & KCNA3_461_473 & P22001 & $\begin{array}{c}\text { Potassium voltage-gated } \\
\text { channel subfamily A member } 3\end{array}$ & 0.055 & 8 & 7 & ONL, IPL & (29) \\
\hline 21. & F263_454_466 & Q16875 & $\begin{array}{c}\text { 6-phosphofructo-2- } \\
\text { kinase/fructose-2,6- } \\
\text { biphosphatase } 3\end{array}$ & 0.059 & 10 & 3 & INL, GCL & \\
\hline 22. & VASP_150_162 & P50552 & $\begin{array}{l}\text { Vasodilator-stimulated } \\
\text { phosphoprotein }\end{array}$ & 0.081 & 8 & 4 & ONL & (23) \\
\hline
\end{tabular}


bioRxiv preprint doi: https://doi.org/10.1101/2021.09.10.459762; this version posted September 11, 2021. The copyright holder for this preprint (which was not certified by peer review) is the author/funder, who has granted bioRxiv a license to display the preprint in perpetuity. It is made available under aCC-BY-NC-ND 4.0 International license.

Roy, Tolone et al., 2021

PKG activity profile in retinal degeneration.

\section{Putative biological pathways involved in retinal degeneration}

To identify possible associations of the kinases with biological pathways that are activated in retinal degeneration as represented by $r d 1$ explants, we performed an analysis of relevant biochemical pathways using the Kyoto Encyclopedia of Genes and Genomes (KEGG; Version 2021).

Pathway analysis of kinase activity in rd1 vs WT explants yielded as the major associated pathways Neurotrophin signaling pathway, proteoglycans in cancer, circadian entrainment, insulin resistance, HIF-1 signaling pathway, long-term potentiation, MAPK signaling (Fig. 4 a). After treatment of $r d 1$ explants with $\mathrm{CNO3}$, the high scoring pathways i.e. insulin resistance, mTOR, MAPK signaling, longterm potentiation, circadian entrainment, and HIF-signaling (Fig. 4 b) were the same as found in Fig 4a.
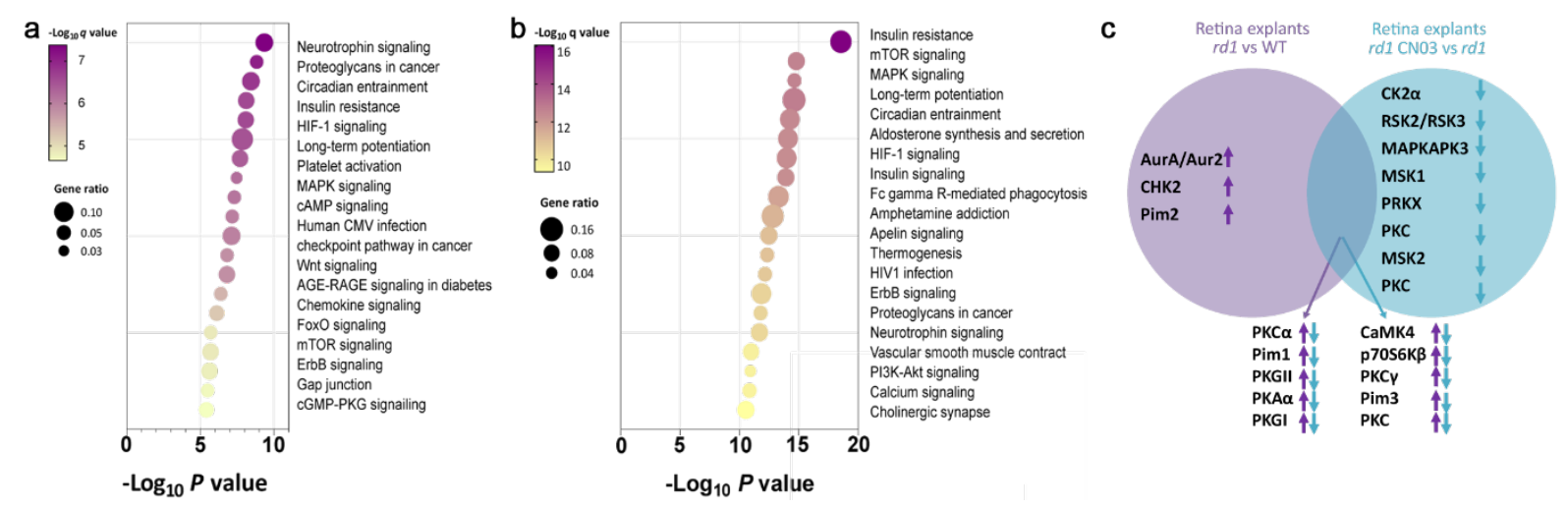

Figure 4. Biological pathways involved in retinal degeneration. Key biological pathways potentially higher activity in $r d 1$ (a) and lower activity in $r d 1$ treated with $\mathrm{CNO} 0$ (b). Pathways are ranked according to their $p$ values and colored by their $q$-values. A $q$ value is the $p$-value adjusted for multiple testing using the Benjamini-Hochberg procedure $(36,37)$. The node size indicates the gene ratio, i.e., the percentage of total genes or proteins in the given KEGG pathways (only input genes or proteins with at least one KEGG pathway were included in the calculation). Node color represents the false discovery rate. c) The overlap between kinases changed in $r d 1$ NT vs WT and vs $r d 1$ treated with CN03 respectively, is visualized in a Venn Diagram. Here, increased or reduced activity of a kinase is indicated by arrows pointing up- or down-wards, respectively.

To identify the putative kinases involved in retinal degeneration based on rd1 model and PKG inhibitor $\mathrm{CNO}$ treatment, we compared the kinases list derived from each comparison as represented in a Venn diagram (Fig. 4 c). Here, almost $77 \%$ of kinases with high activity in $r d 1$ as compared to WT were overlapping with the kinases with reduced activity in $r d 1$ retinal explants treated with CNO3.

\section{PKG target validation for retinal localization}

Next, we tested whether peptides that were differentially phosphorylated in the three retinal explant groups (i.e., WT, $r d 1$, and $r d 1 / \mathrm{CNO}$ ) were expressed in the retina. While some of the corresponding proteins had already previously been shown to be present in mouse retina (Table 2), we performed immunostaining on retinal tissue sections derived from P11 WT mice to assess the 
bioRxiv preprint doi: https://doi.org/10.1101/2021.09.10.459762; this version posted September 11 2021. The copyright holder for this preprint (which was not certified by peer review) is the author/funder, who has granted bioRxiv a license to display the preprint in perpetuity. It is made available under aCC-BY-NC-ND 4.0 International license.

Roy, Tolone et al., 2021

PKG activity profile in retinal degeneration.

retinal expression and cellular localization for six proteins with high PKG preference (Table 2) and potentially connected to photoreceptor degeneration.

The analysis of the WT retinal sections immunostained for Cyclic AMP-responsive element-binding protein 1 (CREB1) showed a near ubiquitous distribution in all nuclear layers of the retina (Fig. 5). The potassium voltage-gated channel subfamily $\mathrm{A}$, member $3\left(\mathrm{~K}_{\mathrm{v}} 1.3\right.$; KCNA3) was found to be localised in the ONL, possibly in photoreceptor axons, and in two discrete sublamina of the IPL (38), where the synapses between bipolar cell axons and ganglion cell dendrites reside. The potassium voltage-gated channel subfamily A, member $6\left(K_{v} 1.6\right.$; KCNA6) was expressed in the ganglion cell layer $(\mathrm{GCL})$ and the nerve fibre layer (NFL). DNA topoisomerase 2- $\alpha$ (TOP2A) expression was restricted to the GCL. 6phosphofructo-2-kinase/fructose-2,6-biphosphatase 3 (F263) - an enzyme involved in the control of glycolytic flux (39) appeared to be present in the OPL, likely in horizontal cells, as well as in the GCL. Finally, staining with the antibody directed against glutamate ionotropic receptor kainate 2 (GRIK2) confirmed its presence in the INL and GCL, in line with previous findings (31). Taken together, the immunostaining data confirm the retinal expression of several of the discovered PKG targets (24) (Fig. 5). The difference in phosphorylation of these targets between $\mathrm{WT}, r d 1$ and $r d 1 / \mathrm{CN} 03$ retinas may suggest a potential role for these PKG substrates in the mechanism leading to photoreceptor cell death.

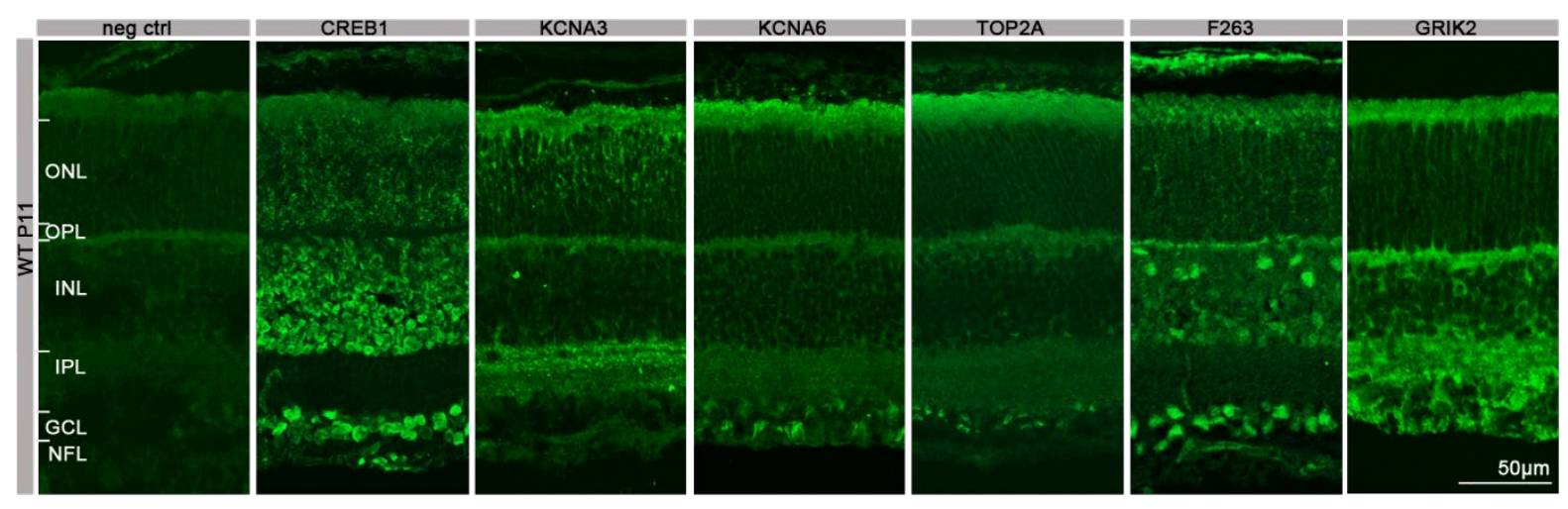

Figure 5: Expression and localisation of PKG target proteins in the retina. The panel shows retinal cross-sections derived from P11 WT mice and stained with secondary antibody for negative control (neg. ctrl.), anti-CREB1, anti-KCNA3, ant-KCNA6, anti-TOP2A, anti-F263, or anti-GRIK2. ONL=outer nuclear layer, OPL=outer plexiform layer, INL=inner nuclear layer, IPL=inner plexiform layer, GCL=ganglion cell layer, NFL=nerve fibre layer. 


\section{Discussion}

Excessive activity of PKG has been directly linked to photoreceptor cell death and its inhibition has been shown to provide photoreceptor protection in several in vivo IRD models $(20,21)$. Yet, at present it is still unclear how PKG exerts its detrimental effects and what the protein targets are that, when phosphorylated by PKG, mediate photoreceptor cell death. Here, we combined PKG inhibitor treatment with multiplex peptide microarray technology and immunohistochemistry to identify novel PKG phosphorylation targets in the retina.

\section{PKG inhibition mediates photoreceptor neuroprotection}

Over-activation of PKG has been connected to neuronal cell death in different experimental settings and conditions, including in human neuroblastoma derived cell cultures (40), peripheral nerve injury (41), and in photoreceptor degeneration $(5,42)$. For photoreceptor degeneration an excessive accumulation of cGMP was already established in the 1970s and while it had already then become evident that high cGMP-levels were cytotoxic $(43,44)$, it was unclear how cGMP would exert its negative effects. Research initially focussed on a proposed detrimental role of cyclic-nucleotide-gated (CNG) channels $(45,46)$, however, in recent years it has become increasingly obvious that PKGsignalling plays a major role in photoreceptor degeneration $(20,47)$. Our study, showing that the inhibitory cGMP analogue CNO3 reduces photoreceptor cell death, is in line with earlier studies in which PKG inhibitors were found to preserve photoreceptor viability and functionality in a variety of models for inherited photoreceptor degeneration $(20,21)$. Nevertheless, what protein targets of PKG exactly are responsible for its cell death promoting effects is unclear. Since PKG may phosphorylate hundreds of substrates it is important to identify those relevant for degeneration in a tissue and cell type specific context (48).

\section{PKG inhibition and peptide microarray technology for the prediction of PKG phosphorylation targets}

To identify the biological pathways leading to photoreceptor cell death, the kinase activity of retinal samples was studied on the PamChip ${ }^{\circledR}$ microarray platform, which allowed investigating the phosphorylation status of 142 peptides simultaneously. The $r d 1$ retinal explants showed an overall increased phosphorylation of peptides, indicating a higher kinase activity and the possible involvement of kinases from the AGC and CAMK families. Substrates to both isoforms of PKG; PKG1 and PKG2 showed higher activity in $r d 1$ retina as indicated by higher phosphorylation (Table 2). The specific inhibition of PKG activity with the inhibitor $\mathrm{CNO}$ in organotypic retina explants allowed to profile kinase activity and response to PKG inhibition using PamChip ${ }^{\circledR}$ technology. CNO3 treatment showed a decrease in peptide phosphorylation with significantly reduced signal on seventeen 
bioRxiv preprint doi: https://doi.org/10.1101/2021.09.10.459762; this version posted September 11, 2021. The copyright holder for this preprint (which was not certified by peer review) is the author/funder, who has granted bioRxiv a license to display the preprint in perpetuity. It is made available under aCC-BY-NC-ND 4.0 International license.

Roy, Tolone et al., 2021 PKG activity profile in retinal degeneration.

peptides. Among the significantly regulated peptides, CREB1_126_38 has already been reported as PKG1 substrate (24). VASP, another well-known PKG substrate $(21,24)$, was also affected, but ranked much lower on our substrate list (rank 22), suggesting that in a retinal context PKGs may prefer other substrates.

Recent studies identified additional cGMP-interacting proteins such as PKAs, PKCs, and CaMKs as upregulated in IRD retinas, which might be interesting in developing new therapeutic targets $(49,50)$. These recent findings corresponded well with our study where we also identified these same kinases as activated in $r d 1$ diseased retinal explants and inhibited by the PKG inhibitor, CN03. The significant difference in phosphorylation between untreated $r d 1$ and $C N 03$-treated $r d 1$ retinal explants indicates that PKG inhibition influenced phosphorylation of these peptides, whose corresponding proteins are therefore candidate PKG targets in situ and may play a role in the mechanism of photoreceptor cell death. We focused on those peptides for which PKG has a high preference, i.e., peptides with a high PKG score (Table 2), and confirmed their presence in the retina by either literature search or by additional immunofluorescence analysis.

\section{Novel targets for PKG in the neuroretina}

One of the identified targets in our analysis was KCNA6, which, together with KCNA3 (rank 20 based on $\mathrm{p}$ value), belongs to the Kv1 family of voltage-dependent potassium channels. The Kv1 family mainly consists of channels with a slow and delayed activation. Immunoreactivity studies revealed expression of both KCNA3 and KCNA6 in the mouse retina (29), which is in line with our immunofluorescence results. The Kv1 family is involved in the regulation of progression through cell cycle checkpoints by defining the membrane potential and ensuring the driving force for calcium and chloride entry. Surprisingly, these proliferation-related channels also appear to play a role in regulating cell death, making them interesting for our study (51). It has been shown that within a few minutes of apoptosis induction KCNA3 is inhibited by the cluster of differentiation 95 (CD95) via tyrosine phosphorylation (52). Other studies have shown the activation of KCNA3 at an early stage of apoptosis, as well as its contribution to a decrease in apoptotic volume, also known as 'cell shrinkage' in lymphocytes (53). In the retina, inhibition of KCNA1 and KCNA3 in vivo was protective for retina ganglion cells (RGCs) after optic nerve axotomy (54). The localization of KCNA6 and KCNA3 in the WT mouse retina and their different phosphorylation by PKG in $r d 1$ and $\mathrm{CNO} 3$ treated $r d 1$ retinal explant cultures suggest a role in photoreceptor cell death. Past studies on the involvement of Kv1 channels in cell death, although conflicting, strengthen this idea (51-53). Establishing whether PKG-mediated phosphorylation of Kv1 channels involves activation or inhibition of these channels would help shed light on their contribution to photoreceptor death. 
bioRxiv preprint doi: https://doi.org/10.1101/2021.09.10.459762; this version posted September 11, 2021. The copyright holder for this preprint (which was not certified by peer review) is the author/funder, who has granted bioRxiv a license to display the preprint in perpetuity. It is made available under aCC-BY-NC-ND 4.0 International license.

Roy, Tolone et al., 2021

PKG activity profile in retinal degeneration.

Among the various differentially phosphorylated substrates located in the retina of both $r d 1$ and WT, CREB1 is a known target of PKG $(55,56)$. CREB1 is a transcription factor implicated in neuronal survival (57) and constitutively expressed in different types of human cancer (58). As shown by the ex vivo results, CREB1 is widely distributed in the mouse retina. Furthermore, through upstream kinase analysis we predicted the activation of several other kinases such as CaMK4, PKC theta, and PKA, known to target CREB (59-61). Thus, the abnormal activity of PKG as well as that of the other kinases can lead to increased CREB1 phosphorylation, in contrast to previous studies in which downregulation of CREB1 was associated with photoreceptor degeneration in both $r d 1$ and $r d 10$ mice $(22,62)$. The increase in activity of kinases that phosphorylate CREB combined with an increase in CREB peptide phosphorylation in $r d 1$ may be due to the activation of parallel signals after the cellular insult: the induction of cell death and the activation of a CREB1-directed survival program (63).

Other PKG targets that we have identified and localized in the retina include vitronectin (VTNC) and F263. VTNC is a cell adhesion protein, upregulated in inflammation and traumatized tissues (64) and a major component of extracellular deposits specific to age-related macular degeneration (AMD) (65). In the same study, VTNC mRNA expression has been found distributed in the various layers of the human retina. Its high phosphorylation in $r d 1$ explants might be linked to increased inflammation, which is an early phenomenon observed for degenerative retinal disorders such as RP, AMD, and diabetic retinopathy (DR) (66). If so, VTNC would have the potential to be a predictive biomarker for certain retinal degenerative diseases.

6-phosphofructo-2-kinase/fructose-2,6-biphosphatase 3 or F263 is a pro-glycolytic enzyme. Its activation following excitotoxic stimulation has been associated with neuronal cell death (67). Furthermore, dysregulation of the HIF1- F263 pathway has been proposed as crucial for two key aspects of the pathogenesis of DR, namely angiogenesis and neurodegeneration (68). With ex vivo analysis we localized F263 in GCL and INL while it was not detected in ONL. The identification of F263 as a target of PKG and its high phosphorylation in $r d 1$ compared to WT suggests a change in retinal energy metabolism during degeneration and may also help to understand the mechanism of aerobic glycolysis in the retina, which remains relatively poorly understood to date (69).

\section{Metabolic pathways in the retina regulated by PKG}

The pathway analysis showed insulin resistance and mTOR as the top pathways inhibited by CNO3. mTOR is a serine/threonine kinase which regulates protein synthesis, cellular metabolism and autophagy (70). The mTOR pathway regulates neurogenesis in the eye and is crucial to normal development of retina and the optic nerve (71). Activated mTOR signaling has been shown to be involved in retinal neurodegenerative diseases such as DR and AMD $(72,73)$. Treatment with the mTOR 
inhibitor rapamycin, improved mitochondrial dysfunction and provided neuroprotection to $661 \mathrm{~W}$ cells, a cellular model that share certain features with photoreceptors (74). Similarly, inhibition of the mTOR/PARP-1 axis leads to photoreceptor protection against light-induced photoreceptor cell death (70). However the targeting of this pathway axis in IRD as treatment strategy is still contentious as there are also studies that show mTOR stimulation delays cone cell death in IRD $(75,76)$.

Among the peptides whose phosphorylation was high in untreated $r d 1$ retinal explants and significantly decreased in CN03-treated $r d 1$ retinal explants was F263, a key regulator of glycolysis (77). Photoreceptors metabolize glucose through aerobic glycolysis (the 'Warburg effect') to satisfy their energy demand for the maintenance of the dark current, as well as the recycling of visual pigments and the renewal of photoreceptor OS $(78,79)$. As a consequence of the high energy demand, the retina has an elevated oxygen consumption, probably the highest in the body, and is therefore particularly prone to oxidative stress and reactive oxygen species (ROS)-induced mitochondrial damage (80). The high phosphorylation of $\mathrm{F} 263$ found in the $r d 1$ retina may be linked to an abnormal increase in metabolic activity in the retina resulting in mitochondrial damage. Considering that mitochondrial dysfunction has been associated with RP (80), the identification of F263 as a substrate of PKG and its possible role in the degeneration process could help to clarify the metabolic state of the diseased retina.

\section{Conclusion}

Using multiplex peptide kinase array technology, we provide further evidence for the likely involvement of PKG in degenerating rd1 photoreceptors in vitro and confirmed the already known neuroprotective effects of the PKG inhibitor CNO3 (21). Furthermore, we identified several novel downstream PKG targets that might play a role in cGMP/PKG-mediated photoreceptor degeneration. This will form the basis for future studies which may further elucidate the role of PKG target phosphorylation as well as the beneficial effects of $\mathrm{CNO}$ and could, furthermore, determine their relevance as novel diagnostic and therapeutic biomarkers for retinal degenerative diseases. For example, the use of phospho-specific antibodies may allow to confirm a reduction of target phosphorylation and, in in situ studies, allow to localize in which cellular compartment it occurred. Finally, our results further connect several metabolic pathways with retinal degeneration, including insulin, mTOR, and Hif1 signaling, which in future studies may help to understand the complex mechanisms behind photoreceptor cell death. 


\section{Materials and Methods}

Animals: $\mathrm{C}^{\mathrm{H}}$ Pde6b ${ }^{\text {rd1/rd1 }}(r d 1)$ and congenic C3H wild-type (WT) mice were housed under standard light conditions, had free access to food and water, and were used irrespective of gender. All procedures were performed in accordance with the law on animal protection issued by the German Federal Government (Tierschutzgesetz) and approved by the institutional animal welfare office of the University of Tübingen.

CGMP analogues synthesis. Synthesis of the cyclic nucleotide analogue $\mathrm{CNO3}$ was performed by Biolog Life Science Institute $\mathrm{GmbH}$ \& Co. KG according to previously described methods (21) (https://patentscope.wipo.int/search/en/detail.jsf?docld=WO2018010965)

Organotypic retinal explant cultures: Preparation of organotypic retinal cultures derived from $r d 1(n=$ $10)$ and $\mathrm{C} 3 \mathrm{H}(\mathrm{n}=5)$ animals was performed as described previously $(26,81)$. Animals were sacrificed at postnatal day (P)5. Eyes were rapidly enucleated and incubated in R16 serum-free, antibiotic-free culture medium (07491252A; Gibco) with 0.12\% proteinase K (21935025; ICN Biomedicals Inc.) for 15 min at $37^{\circ} \mathrm{C}$. Subsequently, eyes were incubated in $20 \%$ foetal bovine serum (FCS) (F7524; Sigma) in order to block proteinase $\mathrm{K}$ activity. This step was followed by rinsing in R16 medium. Under a laminarflow hood and sterile conditions, the anterior segment, lens, vitreous, sclera, and choroids were removed from the eyes. The retina with the RPE still attached was cut in four points resembling a fourleaf clover and transferred to a culture membrane insert (3412; Corning Life Sciences) in a six-well culture plates with completed R16 medium with supplements (26). The retinal explants were incubated at $37^{\circ} \mathrm{C}$ in a humidified $5 \% \mathrm{CO} 2$ incubator and left undisturbed for $48 \mathrm{~h}$. At P7 and P9 medium was changed every second day i.e. with replacement of the full volume of the complete R16 medium, $1 \mathrm{~mL}$ per dish, with fresh medium. In this context, retinal explants were either treated with CNO3 at 50 $\mu \mathrm{M}$ (dissolved in water) or kept as untreated control. For retinal explant lysis, culturing was stopped at $\mathrm{P} 11$, retinal explants were snap frozen in liquid nitrogen and stored at $-80^{\circ} \mathrm{C}$. For retinal explants cross-sectioning preparation, culturing was stopped at P11 by $45 \mathrm{~min}$ fixation in $4 \%$ paraformaldehyde (PFA), cryoprotected with graded sucrose solutions containing 10,20 , and $30 \%$ sucrose, embedded in optimal cutting temperature compound (Tissue-Tek) and then cut into $12 \mu \mathrm{m}$ sections.

TUNEL assay: Representative results showing the protective effects of $\mathrm{CNO} 3$ on photoreceptor cell death at a concentration of $50 \mu \mathrm{M}$, were obtained using terminal deoxynucleotidyl transferase dUTP nick end labelling (TUNEL) assay (82) (based on in Situ Cell Death Detection Kit, 11684795910, red fluorescence; Sigma-Aldrich) on sections derived from $r d 1$ and $\mathrm{C} 3 \mathrm{H}$ retinal explant cultures. DAPI 
(Vectashield Antifade Mounting Medium with DAPI; Vector Laboratories) was used as blue fluorescence nuclear counterstain. Images were captured using 7 Z-stacks with maximum intensity projection (MIP) on a Zeiss Axio Imager Z1 ApoTome Microscope MRm digital camera (Zeiss, Oberkochen, Germany) with a 20x APOCHROMAT objective. The excitation ( $\left.\lambda_{E x c}\right) /$ emission $\left(\lambda_{E m}\right.$.) characteristics of the filter sets used for the fluorophores were as follows (in nm): DAPI $\left(\lambda_{E x c}=369\right.$ $\left.\mathrm{nm}, \lambda_{E m} .=465 \mathrm{~nm}\right)$ and TMR red $\left(\lambda_{E x c}=562 \mathrm{~nm}, \lambda_{E m}=640 \mathrm{~nm}\right.$ ). Adobe Photoshop (CS5Adobe Systems Incorporated, San Jose, CA) was used for image processing.

Materials for retina explant lysis: Mammalian protein extraction reagent (M-PER ${ }^{\mathrm{TM}}$ ), Halt $^{\mathrm{TM}}$ protease and phosphatase inhibitor cocktails and the Coomassie Plus (Bradford Assay) kit were purchased from Thermo Fischer Scientific.

Retinal Explant Lysis: The retinal explant samples were lysed with lysis buffer (MPER with 1:100 phosphatase inhibitor cocktail and protease inhibitor cocktail reagents) for 30 mins on ice. The lysate was centrifuged at $16000 \times \mathrm{g}$ for $15 \mathrm{~min}$ at $4{ }^{\circ} \mathrm{C}$. The supernatant was immediately aliquoted, flash frozen, and stored at $-80{ }^{\circ} \mathrm{C}$. The protein content of the lysate was measured using the Bradford Protein Assay (83).

Kinase activity measurements: The kinase activity for the retina lysates was determined on STK PamChip with four arrays, each comprising of 142 peptides derived from the human phosphoproteome, according to the instructions of the manufacturer (PamGene International B.V., 'shertogenbosch, North Brabant, The Netherlands). The peptide names consist of the protein they are derived from and the first and last amino acid positions in that protein. The phosphorylated Serine/Threonine amino acid residues are detected by a primary antibody mix, which is then confirmed by addition of FITC-conjugated secondary antibody (84). The assay mix consisted of protein kinase buffer (PamGene International BV. 's-Hertogenbosch, North Brabant, The Netherlands), 0.01\% BSA, STK primary antibody mix, ATP $(400 \mu \mathrm{M})$ and retina tissue lysate $(0.25 \mu \mathrm{g} /$ array $)$.

Instrumentation for kinase activity measurements: All the experiments were performed on PamStation $12^{\circ}$ where up to 12 assays can be performed simultaneously (PamGene International B.V., 's-Hertogenbosch, North Brabant, The Netherlands). To prevent unspecific antibody binding, the PamChips ${ }^{\circ}$ were first blocked with $2 \% \mathrm{BSA}$, by pumping it up and down 30 times through the arrays. The chips were then washed three times with Protein Kinase Buffer and assay mix was applied. The assay mix was pumped up and down through the arrays for 60 mins. Afterwards, the arrays were 
bioRxiv preprint doi: https://doi.org/10.1101/2021.09.10.459762; this version posted September 11, 2021. The copyright holder for this preprint (which was not certified by peer review) is the author/funder, who has granted bioRxiv a license to display the preprint in perpetuity. It is made available under aCC-BY-NC-ND 4.0 International license.

Roy, Tolone et al., 2021 PKG activity profile in retinal degeneration.

washed and FITC labelled secondary antibody mix was applied on the arrays. The images of the arrays were recorded at multiple exposure times (85).

Data analysis: The signal intensity of each peptide spot on the array for each time point was quantified by BioNavigator ${ }^{\circledR}$ software version 6.3.67.0 (PamGene International B.V., 's-Hertogenbosch, North Brabant, The Netherlands). For each spot, the signal intensity at the different exposure times was combined to a single value by exposure time scaling (85). The resulting values were log 2 transformed and the overall differences in STK profile between rd1 NT vs. WT or rd1 CN03 vs. rd1 NT were visualized as Heatmaps and Violin Plots which were generated in R software ((R version 4.0.2, 2020 The $R$ Foundation for Statistical Computing). For heatmaps, hierarchal clustering of peptides was performed using the average-linkage method and clustering was shown as dendrograms on the y-axis of heatmaps. Unpaired $t$-tests were used to determine significant differences $(p<0.05)$ in phosphorylation intensity between the groups. Results were represented as Volcano Plots (GraphPad Prism version 9.2.0).

Upstream kinase analysis: Information on kinases that could be responsible for peptide phosphorylation differences between the two sample groups was obtained through the STK Upstream Kinase Analysis tool of BioNavigator ${ }^{\circledR}(85)$. This software integrates known interactions between kinases and the phosphorylation sites as provided in databases such as HPRD, PhosphoELM, PhosphositePLUS, Reactome, UNIPROT and predicts the differentially active kinases between the groups. The results of this analysis are described by two parameters: The Kinase Statistics, indicating the size and direction of the change for each kinase and the Kinase Score, ranking the kinases by the likelihood of this kinase being involved.

The Kinase Statistic depicts the overall change of the peptide set that represents a kinase. For instance, a larger positive value indicates a larger kinase activity in either $r d 1$ explants in comparison to WT or $\mathrm{CNO}$ 3 treated explants in comparison to untreated explants. The Kinase Score is the result of two permutation analyses. The Kinase Score is calculated by addition of the Significance Score and the Specificity Score. The Significance Score indicates the significance of the change represented by the Kinase Statistic between two groups (using 500 permutations across sample labels). The Specificity Score indicates the specificity of the Kinase Statistic with respect to the number of peptides used for predicting the corresponding kinase (using 500 permutations across target peptides). The kinases are ranked by the Kinase Score. The highest ranking predicted kinases from the significant STK peptide sets are represented on a phylogenetic tree of the human protein kinase family generated in Coral, a web-based application http://phanstiel-lab.med.unc.edu/CORAL/) (86). 
Pathway analysis: Pathway analysis was performed in Enrichr (https://maayanlab.cloud/Enrichr/), which is a comprehensive resource for curated gene sets and a search engine that accumulates biological knowledge for further biological discoveries $(36,37)$. We used differentially phosphorylated peptides and predicted upstream kinases as input list for Erichr analysis. Visualization was performed in GraphPad Prism (version 9) using known matrices from the analysis.

Histology: For retinal cross-section preparation, the eyes were marked nasally and cornea, iris, lens, and vitreous were carefully removed. The remaining eyecups were fixed in 4\% PFA for $2 \mathrm{~h}$ at room temperature. Incubation with graded sucrose solutions was performed for cryoprotection. Eyes were embedded in Tissue- Tek and cut into $14 \mu \mathrm{m}$ sections. Immunostaining was performed by incubating with primary antibody against rabbit CREB1 (1:200; Proteintech), KCNA3 (1:200; Alomone labs), KCNA6 (1:300; Alomone labs), F263 (1:100; Abcam), TOP2A (1:500; Proteintech), GRIK2 (1:100; Invitrogen), at $4{ }^{\circ} \mathrm{C}$ overnight. Alexa Fluor 488 antibody was used as secondary antibody. Sections were mounted with DAPI. Images were captured using 9 Z-stacks with maximum intensity projection (MIP) on a Zeiss Axio Imager Z1 ApoTome Microscope MRm digital camera (Zeiss, Oberkochen, Germany) with a 20x APOCHROMAT objective. The excitation $\left(\lambda_{E x C}\right)$ / emission $\left(\lambda_{E m}.\right)$ characteristics of the filter sets used for the fluorophores were as follows (in nm): DAPI $\left(\lambda_{E x c}=369 \mathrm{~nm}, \lambda_{E m .}=465 \mathrm{~nm}\right)$ and AF488 $\left(\lambda_{E x c}=490 \mathrm{~nm}, \lambda_{E m}=525 \mathrm{~nm}\right)$. Adobe Photoshop (CS5Adobe Systems Incorporated, San Jose, CA) was used for image processing.

\section{Conflict of interest statement}

$A R, T T, R H, J G$ are current or former employees of PamGene International B.V., 's-Hertogenbosch, The Netherlands. FPD is shareholder of the company Mireca Medicines, Tübingen, Germany, which intends to forward clinical testing of CNO3.

\section{Acknowledgements}

We thank Norman Rieger for excellent technical assistance and Rik de Wijn, Savithri Rangarajan and Faris Naji for helpful discussion on data analysis. This research was funded by the European Union Horizon 2020 Research and Innovation Programme- transMed under the Marie Curie grant agreement No. 765441 [(transMed; H2020- MSCA-765441)]. 
bioRxiv preprint doi: https://doi org/101101/2021.09 10.459762; this version posted September 11, 2021. The copyright holder for this

preprint (which was not certified by peer review) is the author/funder, who has granted bioRxiv a license to display the preprint in perpetuity. It is made available under aCC-BY-NC-ND 4.0 International license.

\section{Supplementary Figures}

a

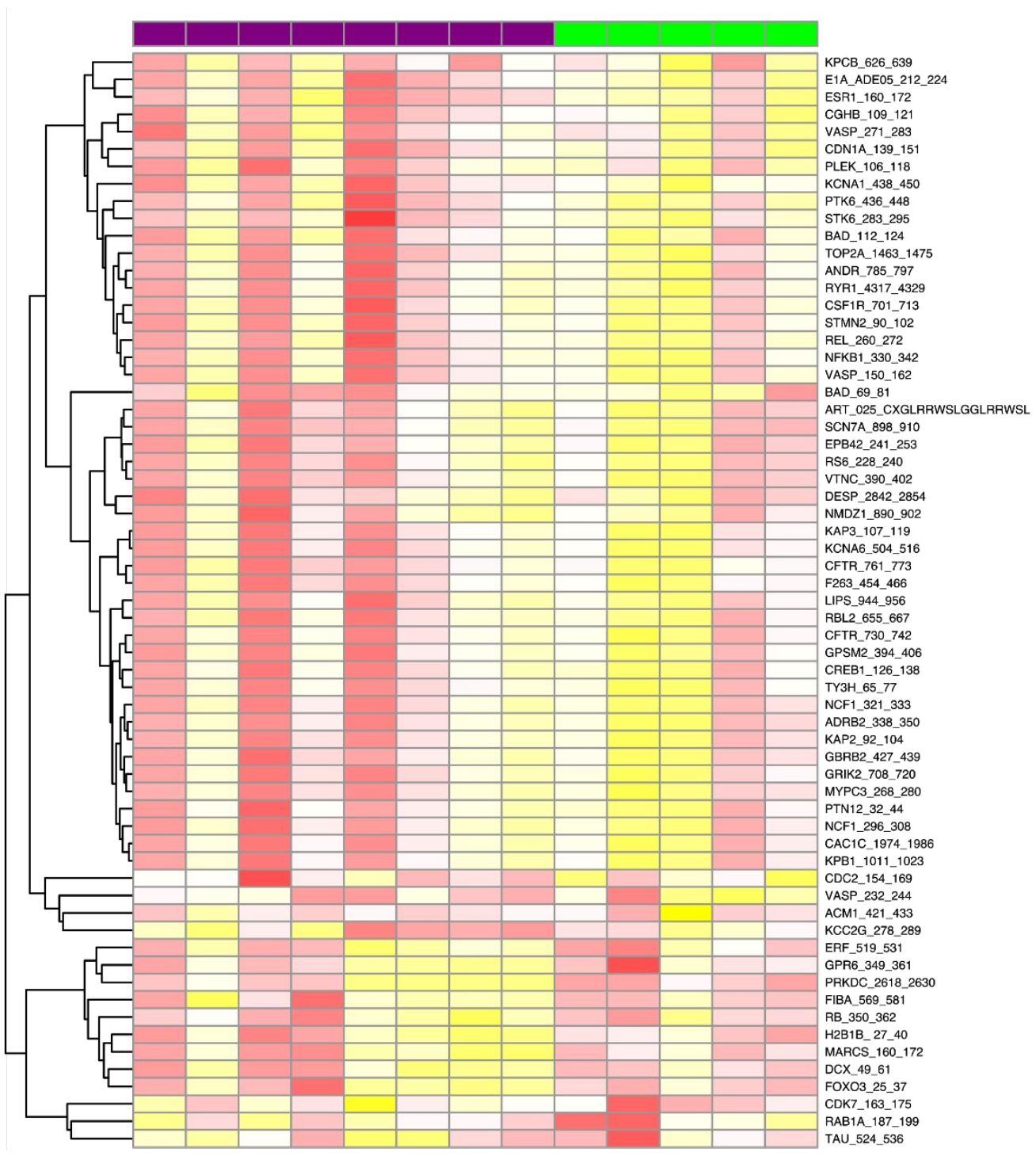

3 GROUP

2 rd1 NT

1

0

$-1$

$-2$

$-3$ 
bioRxiv preprint doi: https://doi org/10.1101/2021.09.10.459762; this version posted September 11, 2021. The copyright holder for this preprint (which was not certified by peer review) is the author/funder, who has granted bioRxiv a license to display the preprint in perpetuity. It is made available under aCC-BY-NC-ND 4.0 International license.

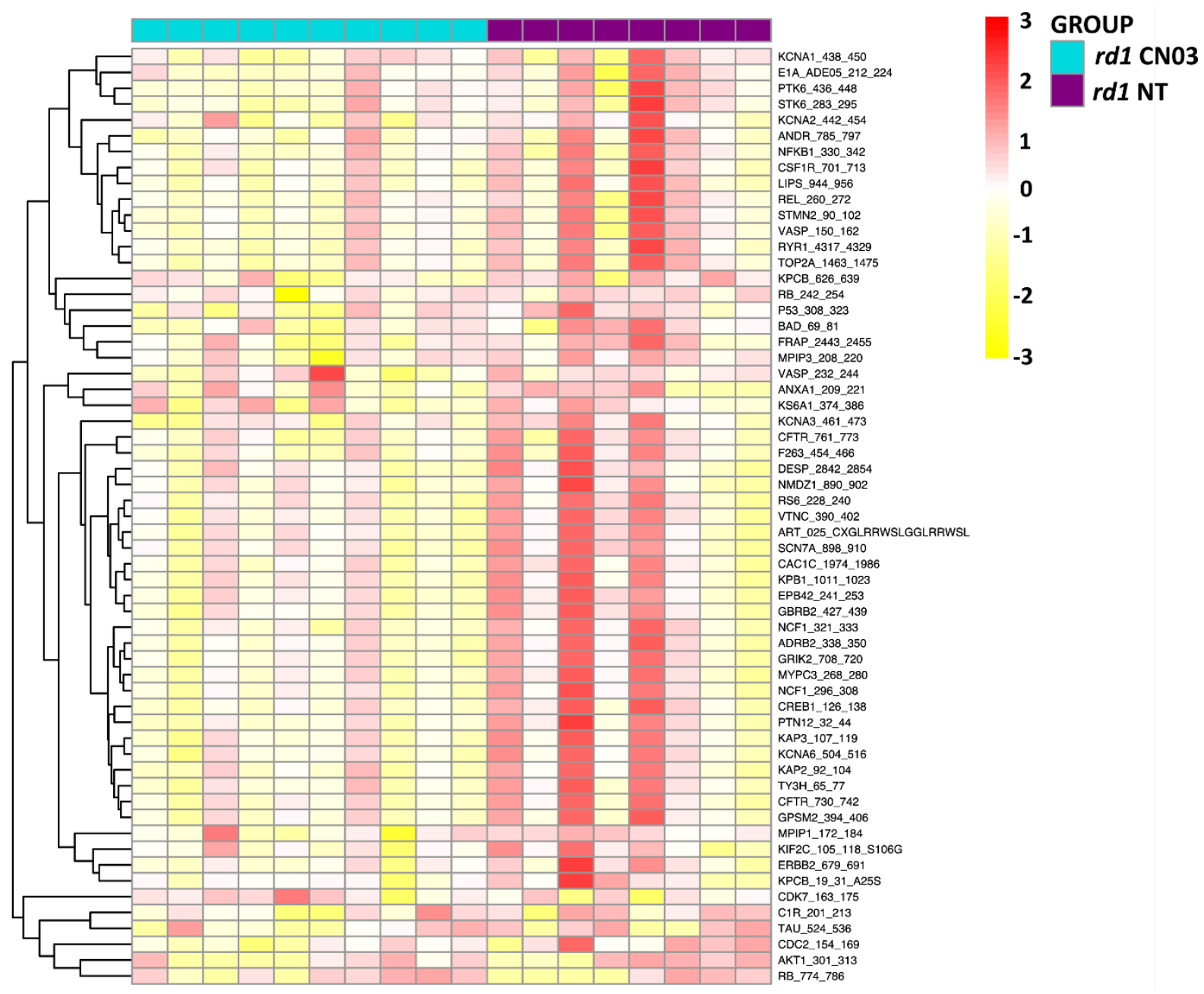

Figure S1. Heatmap representing the overall serine/threonine kinase activity in retinal explants. a) Comparison of protein phosphorylation between $r d 1$ vs. WT retinal explant cultures. b) comparison of CNO3 treated vs. non-treated (NT) rd1 retinal explant cultures. The phosphorylated peptides are clustered hierarchically as explained in 'Data Analysis' section (red=high phosphorylation; yellow=low phosphorylation). 


\section{References}

1. Galan A, Chizzolini M, Milan E, Sebastiani A, Costagliola C, Parmeggiani F. Good Epidemiologic Practice in Retinitis Pigmentosa: From Phenotyping to Biobanking. Curr Genomics. 2011;12(4).

2. Farrar GJ, Carrigan M, Dockery A, Millington-Ward S, Palfi A, Chadderton N, et al. Toward an elucidation of the molecular genetics of inherited retinal degenerations. Vol. 26, Human Molecular Genetics. 2017.

3. Paquet-Durand F, Hauck SM, Veen T Van, Ueffing M, Ekström P. PKG activity causes photoreceptor cell death in two retinitis pigmentosa models. J Neurochem. 2009;108(3):796810.

4. Power M, Das S, Schütze K, Marigo V, Ekström P, Paquet-Durand F. Cellular mechanisms of hereditary photoreceptor degeneration - Focus on cGMP. Prog Retin Eye Res. 2020;74(July 2019).

5. Koch M, Scheel C, Ma H, Yang F, Stadlmeier M, Glück AF, et al. The cGMP-dependent protein kinase 2 contributes to cone photoreceptor degeneration in the Cnga3-deficient mouse model of achromatopsia. Int J Mol Sci. 2021;22(1).

6. Lorenz R, Bertinetti D, Herberg FW. cAMP-dependent protein kinase and cGMP-dependent protein kinase as cyclic nucleotide effectors. In: Handbook of Experimental Pharmacology. 2017.

7. Tang M, Wang G, Lu P, Karas RH, Aronovitz M, Heximer SP, et al. Regulator of G-protein signaling-2 mediates vascular smooth muscle relaxation and blood pressure. Nat Med. 2003;9(12).

8. Antl M, Von Brühl ML, Eiglsperger C, Werner M, Konrad I, Kocher T, et al. IRAG mediates $\mathrm{NO} / \mathrm{cGMP}$-dependent inhibition of platelet aggregation and thrombus formation. Blood. 2007;109(2).

9. Prysyazhna O, Wolhuter K, Switzer C, Santos C, Yang X, Lynham S, et al. Blood PressureLowering by the Antioxidant Resveratrol Is Counterintuitively Mediated by Oxidation of cGMP-Dependent Protein Kinase. Circulation. 2019;140(2).

10. Francis SH, Busch JL, Corbin JD. cGMP-dependent protein kinases and cGMP phosphodiesterases in nitric oxide and cGMP action. Vol. 62, Pharmacological Reviews. 2010.

11. Feil S, Zimmermann P, Knorn A, Brummer S, Schlossmann J, Hofmann F, et al. Distribution of cGMP-dependent protein kinase type $I$ and its isoforms in the mouse brain and retina. Neuroscience. 2005;135(3).

12. French PJ, Bijman J, Edixhoven M, Vaandrager AB, Scholte BJ, Lohmann SM, et al. Isotypespecific activation of cystic fibrosis transmembrane conductance regulator-chloride channels by cGMP-dependent protein kinase II. J Biol Chem. 1995;270(44).

13. Rangaswami H, Marathe N, Zhuang S, Chen Y, Yeh JC, Frangos JA, et al. Type II cGMPdependent protein kinase mediates osteoblast mechanotransduction. J Biol Chem. $2009 ; 284(22)$.

14. Tolone A, Belhadj S, Rentsch A, Schwede F, Paquet-Durand F. The cGMP pathway and inherited photoreceptor degeneration: Targets, compounds, and biomarkers. Genes (Basel). 2019;10(6):1-16. 
15. Quadri M, Comitato A, Palazzo E, Tiso N, Rentsch A, Pellacani G, et al. Activation of cGMPDependent Protein Kinase Restricts Melanoma Growth and Invasion by Interfering with the EGF/EGFR Pathway. J Invest Dermatol. 2021;

16. Arango-Gonzalez B, Trifunović D, Sahaboglu A, Kranz K, Michalakis S, Farinelli P, et al. Identification of a common non-apoptotic cell death mechanism in hereditary retinal degeneration. PLoS One. 2014;9(11):1-11.

17. Farber DB, Park S, Yamashita C. Cyclic GMP-phosphodiesterase of rd retina: Biosynthesis and content. Exp Eye Res. 1988;46(3).

18. Sancho-Pelluz J, Arango-Gonzalez B, Kustermann S, Romero FJ, Van Veen T, Zrenner E, et al. Photoreceptor cell death mechanisms in inherited retinal degeneration. Vol. 38, Molecular Neurobiology. Humana Press Inc.; 2008. p. 253-69.

19. Han J, Dinculescu A, Dai X, Du W, Clay Smith W, Pang J. Review: The history and role of naturally occurring mouse models with Pde6b mutations. Mol Vis. 2013;19.

20. Paquet-Durand F, Hauck SM, Van Veen T, Ueffing M, Ekström P. PKG activity causes photoreceptor cell death in two retinitis pigmentosa models. J Neurochem. 2009;108(3):796810.

21. Vighi E, Trifunovic D, Veiga-Crespo P, Rentsch A, Hoffmann D, Sahaboglu A, et al. Combination of cGMP analogue and drug delivery system provides functional protection in hereditary retinal degeneration. Proc Natl Acad Sci U S A. 2018;115(13):E2997-3006.

22. Paquet-Durand F, Azadi S, Hauck SM, Ueffing M, Van Veen T, Ekström P. Calpain is activated in degenerating photoreceptors in the rd1 mouse. J Neurochem. 2006 Feb;96(3):802-14.

23. Trifunović D, Dengler K, Michalakis S, Zrenner E, Wissinger B, Paquet-Durand F. CGMPdependent cone photoreceptor degeneration in the cpfl1 mouse retina. J Comp Neurol. 2010;518(17).

24. Roy A, Groten J, Marigo V, Tomar T, Hilhorst R. Identification of novel substrates for cGMP dependent protein kinase (PKG) through kinase activity profiling to understand its putative role in inherited retinal degeneration. Int J Mol Sci. 2021;22(3):1-17.

25. Zhao J, Trewhella J, Corbin J, Francis S, Mitchell R, Brushia R, et al. Progressive cyclic nucleotide-induced conformational changes in the cGMP-dependent protein kinase studied by small angle $x$-ray scattering in solution. J Biol Chem. 1997;272(50).

26. Belhadj S, Tolone A, Christensen G, Das S, Chen Y, Paquet-Durand F. Long-term, serum-free cultivation of organotypic mouse retina explants with intact retinal pigment epithelium. J Vis Exp. 2020;2020(165):1-13.

27. Sahaboglu A, Paquet-Durand O, Dietter J, Dengler K, Bernhard-Kurz S, Ekström PAR, et al. Retinitis pigmentosa: Rapid neurodegeneration is governed by slow cell death mechanisms. Cell Death Dis. 2013;4(2).

28. Zeng HY, Tso MOM, Lai S, Lai H. Activation of nuclear factor-KB during retinal degeneration in rd mice. Mol Vis. 2008;14.

29. Höltje M, Brunk I, Große J, Beyer E, Veh RW, Bergmann M, et al. Differential distribution of voltage-gated potassium channels Kv 1.1-Kv1.6 in the rat retina during development. J Neurosci Res. 2007;85(1).

30. Dvoriantchikova G, Grant J, Santos ARC, Hernandez E, Ivanov D. Neuronal NAD(P)H oxidases contribute to ROS production and mediate RGC death after Ischemia. Investig Ophthalmol Vis 
Sci. 2012;53(6).

31. Vila A, Whitaker $\mathrm{CM}, \mathrm{O}^{\prime}$ Brien J. Membrane-associated guanylate kinase scaffolds organize a horizontal cell synaptic complex restricted to invaginating contacts with photoreceptors. J Comp Neurol. 2017;525(4).

32. Anderson DH, Hageman GS, Mullins RF, Neitz M, Neitz J, Ozaki S, et al. Vitronectin gene expression in the adult human retina. Investig Ophthalmol Vis Sci. 1999;40(13).

33. Cammalleri M, Dal Monte M, Amato R, Lapi D, Bagnoli P. Novel Insights into Beta 2 Adrenergic Receptor Function in the rd10 Model of Retinitis Pigmentosa. Cells. 2020;9(9).

34. Ganguly A, Shields CL. Differential gene expression profile of retinoblastoma compared to normal retina. Mol Vis. 2010;16.

35. Huang W, Xing W, Ryskamp DA, Punzo C, Križaj D. Localization and phenotype-specific expression of ryanodine calcium release channels in C57BL6 and DBA/2J mouse strains. Exp Eye Res. 2011;93(5).

36. Xie Z, Bailey A, Kuleshov M V., Clarke DJB, Evangelista JE, Jenkins SL, et al. Gene Set Knowledge Discovery with Enrichr. Curr Protoc. 2021;1(3).

37. Kuleshov M V., Jones MR, Rouillard AD, Fernandez NF, Duan Q, Wang Z, et al. Enrichr: a comprehensive gene set enrichment analysis web server 2016 update. Nucleic Acids Res. 2016;44(W1).

38. Celesia GG, DeMarco PJ. Anatomy and physiology of the visual system. J Clin Neurophysiol. 1994;11(5).

39. Lu Y, Zhang L, Zhu R, Zhou H, Fan H, Wang Q. PFKFB3, a key glucose metabolic enzyme regulated by pathogen recognition receptor TLR4 in liver cells. Ther Adv Endocrinol Metab. 2020;11.

40. Canzoniero LMT, Adornetto A, Secondo A, Magi S, Dell'Aversano C, Scorziello A, et al. Involvement of the nitric oxide/protein kinase $\mathrm{G}$ pathway in polychlorinated biphenylinduced cell death in SH-SY 5 Y neuroblastoma cells. J Neurosci Res. 2006;84(3).

41. González-Forero D, Portillo F, Gómez L, Montero F, Kasparov S, Moreno-López B. Inhibition of resting potassium conductances by long-term activation of the NO/cGMP/protein kinase $\mathrm{G}$ pathway: A new mechanism regulating neuronal excitability. J Neurosci. 2007;27(23).

42. Xu J, Morris L, Thapa A, Ma H, Michalakis S, Biel M, et al. cGMP accumulation causes photoreceptor degeneration in CNG channel deficiency: Evidence of cGMP cytotoxicity independently of enhanced CNG channel function. J Neurosci. 2013;33(37).

43. Farber DB, Lolley RN. Cyclic guanosine monophosphate: Elevation in degenerating photoreceptor cells of the C3H mouse retina. Science (80- ). 1974;186(4162).

44. Lolley RN, Farber DB, Rayborn ME, Hollyfield JG. Cyclic gmp accumulation causes degeneration of photoreceptor cells: Simulation of an inherited disease. Science (80- ). 1977;196(4290).

45. Paquet-Durand F, Beck S, Michalakis S, Goldmann T, Huber G, Mühlfriedel R, et al. A key role for cyclic nucleotide gated (CNG) channels in CGMP-related retinitis pigmentosa. Hum Mol Genet. 2011;20(5).

46. Barabas P, Peck CC, Krizaj D. Do calcium channel blockers rescue dying photoreceptors in the pde6b rd1 mouse? Adv Exp Med Biol. 2010;664:491-9. 
47. Ma H, Butler MR, Thapa A, Belcher J, Yang F, Baehr W, et al. cGMP/protein kinase G signaling suppresses inositol 1,4,5-trisphosphate receptor phosphorylation and promotes endoplasmic reticulum stress in photoreceptors of cyclic nucleotide-gated channel-deficient mice. J Biol Chem. 2015;290(34).

48. Makhoul S, Walter E, Pagel O, Walter U, Sickmann A, Gambaryan S, et al. Effects of the $\mathrm{NO} /$ soluble guanylate cyclase/cGMP system on the functions of human platelets. Vol. 76, Nitric Oxide - Biology and Chemistry. 2018.

49. Rasmussen M, Welinder C, Schwede F, Ekström P. The cGMP system in normal and degenerating mouse neuroretina: New proteins with cGMP interaction potential identified by a proteomics approach. J Neurochem. 2020;(July):1-14.

50. Roy A, Hilhorst R, Groten J, Paquet-Durand F, Tomar T. Technological advancements to study cellular signaling pathways in inherited retinal degenerative diseases. Vol. 60, Current Opinion in Pharmacology. 2021.

51. Bachmann M, Li W, Edwards MJ, Ahmad SA, Patel S, Szabo I, et al. Voltage-Gated Potassium Channels as Regulators of Cell Death. Vol. 8, Frontiers in Cell and Developmental Biology. 2020.

52. Szabò I, Gulbins E, Apfel H, Zhang X, Barth P, Busch AE, et al. Tyrosine phosphorylationdependent suppression of a voltage-gated $\mathrm{K}+$ channel in T lymphocytes upon Fas stimulation. J Biol Chem. 1996;271(34).

53. Storey NM, Gómez-Angelats M, Bortner CD, Armstrong DL, Cidlowski JA. Stimulation of Kv1.3 Potassium channels by death receptors during apoptosis in Jurkat T lymphocytes. J Biol Chem. 2003;278(35).

54. Koeberle PD, Schlichter LC. Targeting KV channels rescues retinal ganglion cells in vivo directly and by reducing inflammation. Channels. 2010;4(5):337-46.

55. Butt E, Abel K, Krieger M, Palm D, Hoppe V, Hoppe J, et al. cAMP- and cGMP-dependent protein kinase phosphorylation sites of the focal adhesion vasodilator-stimulated phosphoprotein (VASP) in vitro and in intact human platelets. J Biol Chem. 1994;269(20).

56. Nagai-Kusuhara A, Nakamura M, Mukuno H, Kanamori A, Negi A, Seigel GM. cAMPresponsive element binding protein mediates a cGMP/protein kinase G-dependent antiapoptotic signal induced by nitric oxide in retinal neuro-glial progenitor cells. Exp Eye Res. 2007;84(1).

57. Finkbeiner S. CREB couples neurotrophin signals to survival messages. Vol. 25, Neuron. 2000.

58. Sakamoto KM, Frank DA. CREB in the pathophysiology of cancer: Implications for targeting transcription factors for cancer therapy. Vol. 15, Clinical Cancer Research. 2009.

59. Azadi S, Paquet-durand F, Medstrand P, Veen T Van, Ekström P. Up-regulation and increased phosphorylation of protein kinase $C$ (PKC) $\delta, \mu$ and $\theta$ in the degenerating rd1 mouse retina. Mol Cell Neurosci. 2006;31(4):759-73.

60. Gonzalez GA, Montminy MR. Cyclic AMP stimulates somatostatin gene transcription by phosphorylation of CREB at serine 133. Cell. 1989;59(4).

61. Bito H, Deisseroth K, Tsien RW. CREB phosphorylation and dephosphorylation: A Ca2+- and stimulus duration-dependent switch for hippocampal gene expression. Cell [Internet]. 1996;87(7):1203-14. Available from: http://dx.doi.org/10.1016/S0092-8674(00)81816-4

62. Dong E, Bachleda A, Xiong Y, Osawa S, Weiss ER. Reduced phosphoCREB in Müller glia during 
retinal degeneration in rd10 mice. Mol Vis. 2017;23.

63. Lonze BE, Ginty DD. Function and regulation of CREB family transcription factors in the nervous system. Vol. 35, Neuron. 2002.

64. Preissner KT, Seiffert D. Role of vitronectin and its receptors in haemostasis and vascular remodeling. Thromb Res. 1998;89(1).

65. Biasella F, Plössl K, Karl C, Weber BHF, Friedrich U. Altered protein function caused by AMDassociated variant rs704 links vitronectin to disease pathology. Investig Ophthalmol Vis Sci. 2020;61(14).

66. Arroba Al, Campos-Caro A, Aguilar-Diosdado M, Valverde ÁM. IGF-1, inflammation and retinal degeneration: A close network. Vol. 10, Frontiers in Aging Neuroscience. 2018.

67. Burmistrova O, Olias-Arjona A, Lapresa R, Jimenez-Blasco D, Eremeeva T, Shishov D, et al. Targeting PFKFB3 alleviates cerebral ischemia-reperfusion injury in mice. Sci Rep. 2019;9(1).

68. Min J, Zeng T, Roux M, Lazar D, Chen L, Tudzarova S. The Role of HIF1 $\alpha$-PFKFB3 pathway in Diabetic Retinopathy. J Clin Endocrinol Metab. 2021;

69. Hurley JB. Retina Metabolism and Metabolism in the Pigmented Epithelium: A Busy Intersection. Annu Rev Vis Sci. 2021;7(1).

70. Pan YR, Song JY, Fan B, Wang Y, Che L, Zhang SM, et al. MTOR may interact with PARP-1 to regulate visible light-induced parthanatos in photoreceptors. Clin Experiment Ophthalmol. 2020;48(8):1072-84.

71. Avet-Rochex A, Carvajal N, Christoforou CP, Yeung K, Maierbrugger KT, Hobbs C, et al. Unkempt Is Negatively Regulated by mTOR and Uncouples Neuronal Differentiation from Growth Control. PLoS Genet. 2014;10(9):e1004624.

72. Sinha D, Valapala M, Shang P, Hose S, Grebe R, Lutty GA, et al. Lysosomes: Regulators of autophagy in the retinal pigmented epithelium. Vol. 144, Experimental Eye Research. 2016.

73. Nakahara T, Morita A, Yagasaki R, Mori A, Sakamoto K. Mammalian Target of Rapamycin (mTOR) as a Potential Therapeutic Target in Pathological Ocular Angiogenesis. Vol. 40, Biological and Pharmaceutical Bulletin. 2017.

74. Fan B, Li FQ, Zuo L, Li GY. mTOR inhibition attenuates glucose deprivation-induced death in photoreceptors via suppressing a mitochondria-dependent apoptotic pathway. Neurochem Int. 2016;99.

75. Petit L, Punzo C. mTORC1 sustains vision in retinitis pigmentosa. Vol. 6, Oncotarget. 2015.

76. Punzo C, Kornacker K, Cepko CL. Stimulation of the insulin/mTOR pathway delays cone death in a mouse model of retinitis pigmentosa. Nat Neurosci. 2009 Jan;12(1):44-52.

77. Porporato PE, Dhup S, Dadhich RK, Copetti T, Sonveaux P. Anticancer targets in the glycolytic metabolism of tumors: A comprehensive review. Front Pharmacol. 2011;AUG.

78. Zhang R, Shen W, Du J, Gillies MC. Selective knockdown of hexokinase 2 in rods leads to agerelated photoreceptor degeneration and retinal metabolic remodeling. Cell Death Dis. 2020;11(10).

79. Léveillard T, Sahel JA. Metabolic and redox signaling in the retina. Cell Mol Life Sci. 2017;74(20):3649-65.

80. Moreno ML, Mérida S, Bosch-Morell F, Miranda M, Villar VM. Autophagy dysfunction and 
oxidative stress, two related mechanisms implicated in retinitis pigmentosa. Vol. 9, Frontiers in Physiology. Frontiers Media S.A.; 2018.

81. Caffé AR, Ahuja P, Holmqvist B, Azadi S, Forsell J, Holmqvist I, et al. Mouse retina explants after long-term culture in serum free medium. J Chem Neuroanat. 2002;22(4):263-73.

82. Loo DT. In situ detection of apoptosis by the TUNEL assay: An overview of techniques. Methods Mol Biol. 2011;682.

83. Zor T, Selinger Z. Linearization of the Bradford protein assay increases its sensitivity: Theoretical and experimental studies. Anal Biochem. 1996;236(2).

84. Hilhorst R, Houkes L, Mommersteeg M, Musch J, Van Den Berg A, Ruijtenbeek R. Peptide microarrays for profiling of serine/threonine kinase activity of recombinant kinases and lysates of cells and tissue samples. Methods Mol Biol. 2013;977:259-71.

85. Chirumamilla CS, Fazil MHUT, Perez-Novo C, Rangarajan S, de Wijn R, Ramireddy P, et al. Profiling activity of cellular kinases in migrating T-cells. Methods Mol Biol. 2019;1930:99-113.

86. Metz KS, Deoudes EM, Berginski ME, Jimenez-Ruiz I, Aksoy BA, Hammerbacher J, et al. Coral: Clear and Customizable Visualization of Human Kinome Data. Cell Syst. 2018;7(3). 